\title{
Keep Cool Bugs Timber Sale Environmental Assessment
}

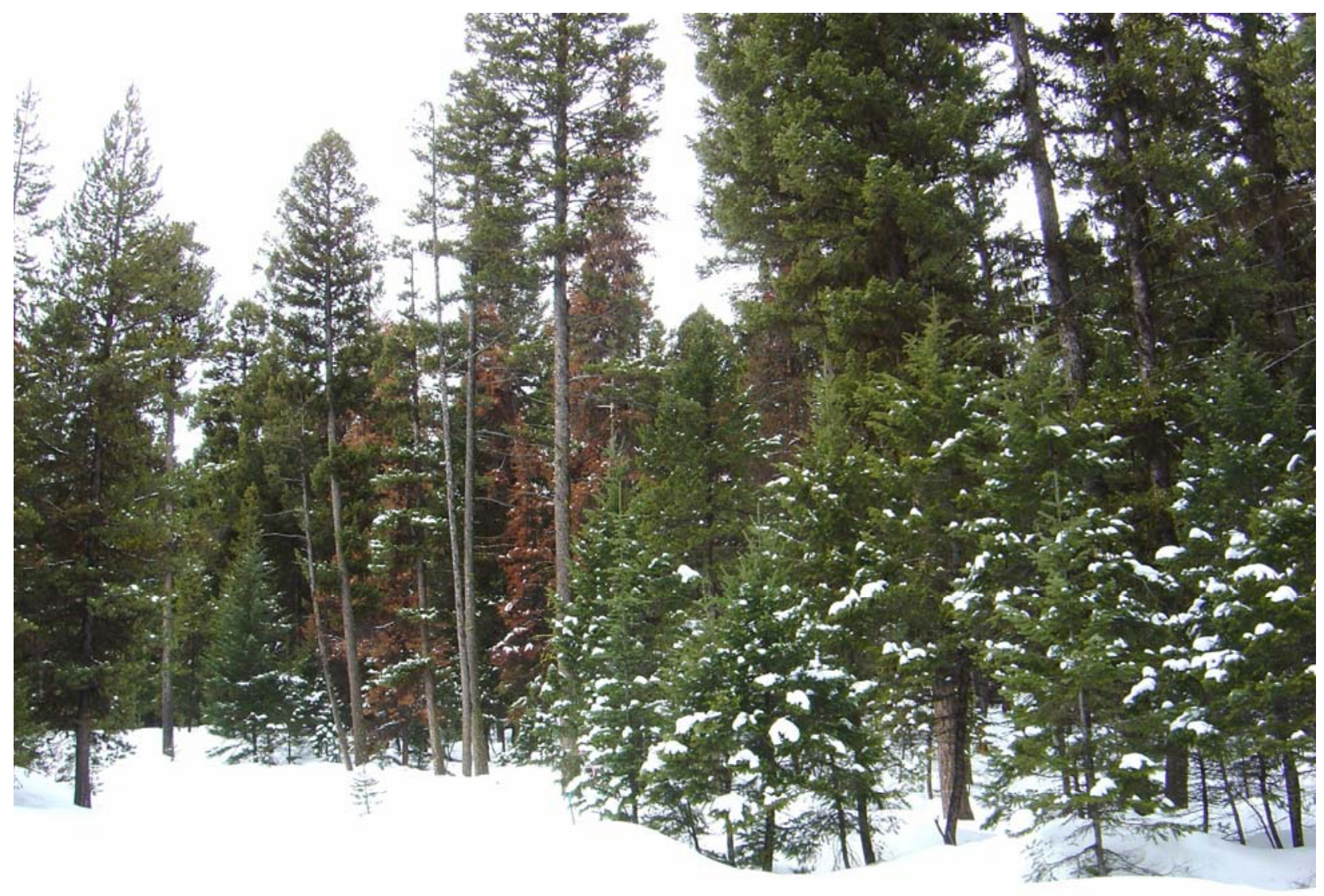

Montana Department of Natural Resources and Conservation

\author{
Southwestern Land Office
}

Lincoln Field Office of the Clearwater Unit

February 28, 2005 


\section{FINDING OF KEEP COOL BUGS SALVAGE SALE}

An Environmental Analysis (EA) has been completed for the proposed Department of Natural Resources and Conservation (DNRC) Keep Cool Bugs Salvage Sale. After a thorough review of the EA, project file, public correspondence, Department policies, standards and guidelines, and the State Forest Land Management Rules (SFLMR), I have made the following 3 decisions:

\section{ALTERNATIVE SELECTED}

Two alternatives are presented and were fully analyzed in this checklist EA: the No-Action Alternative, which includes existing activities, but does not include a timber sale (EA part 3), and the proposed action which proposes salvage and overstory removal of approximately 1.3 million board feet of timber from 208 acres (EA parts 1 and 3).

For the following reasons, I have selected the proposed action without additional modifications:

a. In my opinion, the proposed action best meets the purpose and need for action and the specific project objectives listed in the EA part 1. The environmental effects of the proposed action are acceptable as compared with the no action alternative which does not meet requirements under State law. Silviculturally, this timber sale would salvage insect infested or trees that are at risk of same, and would perform an overstory harvest on 38 acres. Risk of blowdown of these stands would be moderate and has been assessed (Attachment B page 27). The proposed project would decrease the susceptibility of remaining trees to insect and disease infestations on DNRC ownership and neighboring land as well (Attachment B page 29-30), and increase tree vigor (Attachment B page 29-30). The action alternative would reduce the threat of catastrophic wildfire and its potential impact upon areas to the west of Lincoln, MT within the Blackfoot River valley floor (Attachment B page 30-31). There are not any sensitive plants located on the sale area given DNRC surveys and the Montana Natural Heritage Program (Attachment B page 25). Noxious weeds would be treated with an accepted manner of treatment (Attachment B page 3132). No major losses or unacceptable effects to water or soil, or the hydrologic makeup of watercourses would be predicted to occur (EA part 4 and 5, Attachment D). There is a low to moderate risk of losses in habitat (Attachment C, EA parts 8 and 9), or unacceptable effects to Threatened, Endangered, or Sensitive species (Attachment $C$ pages 39-44, EA parts 8 and 9), or big game (Attachment $C$ pages 44-45, EA parts 8 and 9). No effects to fisheries would be expected to occur under the proposed action since no streams exist within the sale area (Attachment D pages 52-53, EA part 8). There are two known cultural resources on this tract (surface stones features labeled 24LC857) but will not be affected by this action (EA part 10). The proposed action generates more return to the school trust than the no action alternative (Attachment $\mathrm{E}$ page 56-57).

b. The analysis of identified issues did not reveal information compelling the DNRC not to implement the proposed action.

c. The proposed action includes activities to address environmental concerns expressed by DNRC staff and the public.

d. All proposed mitigations are adequate and feasible. 


\section{SIGNIFICANCE OF IMPACTS}

For the following reasons, I find that the proposed action would not have significant impacts:

\section{a. Economics}

This proposed project has shown that the only way currently known to achieve a profitable income from these forest stands (especially in the insect ridden condition) is by selecting the Action Alternative. State Law (MCA) 77-5-707 states that the DNRC shall establish a salvage timber program to timely remove timber (dead or dying) from State forests if the economic value provides for its removal (Attachment $\mathrm{E}$ ) and that harvest will help control the insect and disease growth (Attachment B).

\section{b. Forest Health and Vigor}

The action alternative is primarily designed to salvage stands that are under, or will be under, an attack by mountain pine beetle (EA part 1, Attachment B page 28), with approximately 38 acres of overstory removal (Attachment B page 28). The changes made through the treatments should improve forest health and growth on the forested DNRC acres (EA part 3, Attachment B page 28). Vigor and health in almost all of the stands varies greatly, but the rate of insect activity currently occurs in many of the stands within this project (Attachment B pages 26-30). There are also areas of Armellaria spp. root rot within this sale area (Attachment $B$ page 22-23). Blowdown may occur after the harvest. These trees would likely be salvaged if it was economically feasible as part of this project (Attachment B page 30).

\section{c. Hydrology and Fisheries}

As there is not a stream or fishery that is within the project area, no adverse effects are expected (Attachment $\mathrm{D}$ page 53). No direct or indirect cumulative measurements for this sale occur for water quality (Attachment D page 52), and given proper forestry BMP's, all potential soil concerns (soil compaction, road conditions, and travel concerns) are mitigated (Attachment D page 53).

\section{d. Old Growth}

No old growth stands, given ages and methodology used, are present (Attachment B page 25)

\section{e. Threatened, Endangered, Sensitive, and Other Species}

This project area is within the Northern Continental Divide Ecosystem (NCDE) recovery area and has been used recently (Attachment $C$ page 34). The timber sale has been designed to use harvesting scheduling to reduce conflict with grizzly bears (Attachment $C$ page 39-40). It is predicted that effects to grizzly bears will be low to moderate in severity (Attachment $C$ page 40 ). Harvest is predicted to leave a large amount of young Douglas-fir to act as limited cover (Attachment $C$ page 39-40). As the stands within the project area, both on DNRC and on surrounding ownerships, "fill in" the use by Canada Lynx will increase and possibly improve (Attachment $C$ page 41-42) and effects are predicted to be low (Attachment $C$ page 42). Impact to; gray wolves (Attachment $C$ page 41), Fischer (Attachment C page 42), Pileated Woodpecker (Attachment C page 43), black-backed woodpecker (Attachment C page 44), and big game (Attachment $C$ page 44-45), are all low to moderate in severity.

\section{f. Road Use Within the Area.}

This proposed project analysis has determined, due to gently sloping ground and existing roads that often come from adjoining land, a gating system would not be currently feasible as part of this project (EA part 20). This area is used in the winter by snowmobile enthusiasts (EA part 20, Attachment $C$ page 42). 


\section{SHOULD DNRC PREPARE AN ENVIRONMENTAL IMPACT STATEMENT (EIS)?}

Based on the following, I find that an EIS does not need to be prepared:

a. The EA adequately addressed the issues identified during project development and displayed the information needed to make the decisions.

b. Evaluation of the potential impacts of the proposed timber sale indicates that no significant impacts would occur.

c. Sufficient opportunities for DNRC staff and public review and comment during project development and analysis were provided. DNRC staff and public concerns were incorporated into project design and analysis of impacts.

/s/ Craig V. Nelson

Craig V. Nelson

Supervisory Forester

Clearwater Unit

Southwestern Land Office

March 9, 2006 


\section{Table of Contents}

EA Checklist

Attachment A - Maps

Attachment B - Vegetative Resources

Attachment C - Wildlife

Attachment D - Watershed, Fisheries, Soils

Attachment E - Economics

Attachment F - Literature Cited

Attachment G - List of Preparers and Contributors
Pages 6-12

Pages 13-16

Pages 17-32

Pages 33-47

Pages 48-53

Pages 54-57

Pages 58-61

Pages 62-63 


\section{CHECKLIST ENVIRONMENTAL ASSESSMENT}

\begin{tabular}{|c|c|}
\hline $\begin{array}{l}\text { Project Name: } \\
\text { Proposed }\end{array}$ & Keep Cool Bugs \\
\hline Implementation Date: & June 15, 2006 \\
\hline Proponent: & Montana Department of Natural Resources and Conservation \\
\hline Location: & Section 10, T14N, R8W \\
\hline County: & Lewis and Clark \\
\hline
\end{tabular}

\section{TYPE AND PURPOSE OF ACTION}

The Montana DNRC is proposing to harvest approximately 1.3 MMBF of trees from approximately 208 acres. Harvesting would include salvage of mountain pine beetle (Dendroctonus ponderosae) hit trees and other material on approximately 170 acres and an overstory removal on approximately 38 acres as well as planting of ponderosa pine trees on approximately 26 acres. Approximately 0.5 miles of new roads that would be constructed and then gated with an additional 0.2 miles gated and 0.3 miles closed with earth berms. The project objectives are to: 1 ) seek to maximize revenue over the long-term for the School Trust accounts from the timber resources and salvage timber on state forests that is dead or dying or is threatened by insects, disease, fire, or windthrow as mandated by State Statute 77-5-207, MCA, 2) manage the identified parcel intensively for healthy and biologically diverse forests to provide long-term income for the Trust, 3) improve timber stand growth and vigor and reduce the threat of future losses to bark beetles and wildfire, and 4) reduce pine beetle populations by removing infested trees.

\section{PROJECT DEVELOPMENT}

\section{PUBLIC INVOLVEMENT, AGENCIES, GROUPS OR INDIVIDUALS CONTACTED:}

Provide a brief chronology of the scoping and ongoing involvement for this project.

The initial proposal, which was scoped in February of 2006, proposed the harvest of 1.3 MMBF from 207 acres of ground and included the construction of approximately 0.5 miles of road. In addition to public scoping, resource professionals in state and federal agencies were scoped to notify them and receive input. Comments were received from various individuals, organizations, and agencies and grouped into the concerns as well as issues that were identified internally within the DNRC that were used to help guide the development of the action alternative.

The mailing list of parties receiving initial scoping notices for this project is located in the project file at the Lincoln Field Office. Public scoping comments and a list of issues and concerns are also located in the project file at the Lincoln Field Office.

\section{OTHER GOVERNMENTAL AGENCIES WITH JURISDICTION, LIST OF PERMITS NEEDED:}

Montana Department of Environmental Quality - burning restrictions

\section{ALTERNATIVES CONSIDERED:}

Alternative A - No Action. The bark beetle epidemic would likely continue and spread throughout the state ownership as well as adjacent ownerships, and substantial value would be lost. Stands would continue to deteriorate from disease and general poor health. Unhealthy amounts of fuel would continue to accumulate and canopy cover would continue to be reduced. No trees would be planted and no new road would be constructed. 
Alternative B - Action Alternative. Trees infested with bark beetles and trees that are in poorer health would be harvested through a salvage harvest on approximately 170 acres using ground-based harvesting systems. Treatments would reduce beetle populations by removing infested trees, reducing basal areas, and improving tree vigor within the stands. This would reduce the risk of future losses to beetles, and maintain long-term forest health and productivity. Approximately 38 acres would receive an overstory removal harvest and approximately 26 acres would be planted with ponderosa pine (currently planned for planting in the spring of 2008). Approximately 0.5 miles of new road would be constructed. This proposed road would be closed to motorized public use as well as an additional 0.5 miles of road. The bulk of the harvesting would take place in the summer and fall of 2006 with one additional operation in a winter or summer and fall period prior to 10/15/09 for additional salvage that may be needed.

There appear to be no other alternatives that can realistically offer an equivalent opportunity to meet the project objectives for the following reasons:

1. Harvesting as proposed would seek to maximize revenue for the school trust and salvage dead and dying trees as required by state law.

2. The proposed action would ensure that the long-term potential for harvesting timber from these sites would be enhanced by improving current growth rates.

3. Through an interdisciplinary team, revisions were made to the initial proposal to mitigate unresolved conflicts that may have required additional alternatives or created greater impacts.

4. Any alternatives that proposed to harvest more acres would not meet biological and resource goals, and likewise any alternatives that proposed to harvest less acres would not meet revenue and forest health objectives. So a balance was reached that meets the project objectives as well as possible and resulted in the harvest plan of the proposed action alternative.

\section{IMPACTS ON THE PHYSICAL ENVIRONMENT}

- $\quad$ RESOURCES potentially impacted are listed on the form, followed by common issues that would be considered.

- Explain POTENTIAL IMPACTS AND MITIGATIONS following each resource heading.

- Enter "NONE" If no impacts are identified or the resource is not present.

\section{GEOLOGY AND SOIL QUALITY, STABILITY AND MOISTURE:}

Consider the presence of fragile, compactable or unstable soils. Identify unusual geologic features. Specify any special reclamation considerations. Identify any cumulative impacts to soils.

The geology is limestone and volcanic porphyry that has been glacially scoured and covered by glacial till soils. No unstable geology occurs within the section, but there is mineral potential and several old exploratory drill pad sites. Soils on forest sites are shallow to moderate, deep gravelly to clayey in texture with low to moderate erosion risk. Soil disturbance would occur on new roads and to a lesser extent in the skid trail locations. Planned ground skidding operations should have a low risk of direct, in-direct and cumulative soil impacts based on implementing BMP's, mitigation measures and soil monitoring on comparable sites. Mitigations include avoiding excessive soil disturbance, season of use restrictions, and general skid trail planning. See Attachment $\mathrm{D}$ for a detailed effects assessment.

\section{WATER QUALITY, QUANTITY AND DISTRIBUTION:}

Identify important surface or groundwater resources. Consider the potential for violation of ambient water quality standards, drinking water maximum contaminant levels, or degradation of water quality. Identify cumulative effects to water resources.

The proposed salvage harvest of dead, dying and high-risk trees would result in a minor reduction of canopy cover and no measurable water yield increase compared to the current conditions and the current trend towards patches of reduced canopy. There are no streams within the harvest area or near roads. Spring fed seeps and isolated wetlands would be avoided or protected to meet ARM 36.11.462 where they occur. Planned harvest operations and roads present a low risk of direct, in-direct and cumulative impacts based on the implementing BMP's and mitigation measures. Mitigations include adding drainage to roads, season of use restrictions, 
protecting isolated wetlands and prompt revegetation of roads and landings to control erosion. See Attachment D for a detailed effects assessment.

\section{6. $\quad$ AIR QUALITY:}

What pollutants or particulate would be produced? Identify air quality regulations or zones (e.g. Class I air shed) the project would influence. Identify cumulative effects to air quality.

Some slash piles would be created, and when burned there would be some impact to local airsheds. Over $70 \%$ of the emissions emitted from prescribed burning is less than 2.5 microns (National Ambient Air Quality PM 2.5). High, short-term levels of PM 2.5 may be hazardous. Within the typical column of biomass burning, the chemical toxics are: Formaldehyde, Acrolein, Acetaldehyde, 1,4 Butadiene, and Polycyclic Organic Matter.

Federal, state and local agencies enforce rules for open, controlled burning. The post harvest burning of piled debris would produce particulate matter. All burning would be conducted at times of adequate ventilation and within existing rules, plans, and regulations. Air quality is analyzed by estimating emissions from prescribed burns. The air quality analysis area for the proposed action is located in Montana Airshed 6 . The Montana Airshed Group is responsible for determining both airshed number and impact zones. The project area is not located in any of the impact zones.

Prior to burning a "Prescribed Fire Burn Plan" will be completed for the project area.

Cumulative effects to air quality would not exceed the levels defined by State of Montana Cooperative Smoke Management Plan (1988) and managed by the Montana Airshed Group. Prescribed burning by other nearby airshed cooperators (for example Plum Creek Timber Company) would have potential to affect air quality. All cooperators currently operate under the same Airshed Group guidelines. The State, as a member, would burn only on approved days. This should decrease the likelihood of additive cumulative effects.

\section{VEGETATION COVER, QUANTITY AND QUALITY:}

What changes would the action cause to vegetative communities? Consider rare plants or cover types that would be affected. Identify cumulative effects to vegetation.

Vegetative cover would be changed on approximately 170 acres that would be salvage harvested resulting in a range of residual stockings from very low to heavily stocked stand conditions. Another approximately 38 acres would receive an overstory removal treatment. These proposed treatments would result in more open stand conditions, more growing space for residual trees, the removal of beetle infested and beetle killed trees, and the establishment of young, healthy regeneration. Additionally, approximately 26 acres would be planted with ponderosa pine trees. See Attachment B for a detailed effects assessment.

\section{TERRESTRIAL, AVIAN AND AQUATIC LIFE AND HABITATS:}

Consider substantial habitat values and use of the area by wildlife, birds or fish. Identify cumulative effects to fish and wildlife.

The proposed activities would affect wildlife species that use the area by the construction of roads, the closure of roads, disturbance during operations in the area, and by reducing cover. There is a very low risk of negative effects to fish species as a result of the proposed activities. See Attachments $C$ and D for detailed effects assessments.

\section{UNIQUE, ENDANGERED, FRAGILE OR LIMITED ENVIRONMENTAL RESOURCES:}

Consider any federally listed threatened or endangered species or habitat identified in the project area. Determine effects to wetlands. Consider Sensitive Species or Species of special concern. Identify cumulative effects to these species and their habitat.

The proposed activities would affect threatened and endangered and sensitive species that use the area by the construction of roads, the closure of roads, disturbance during operations in the area, and by reducing cover. Species that were considered to be at a low or minimal risk of negative effects and were not analyzed further include: bald eagle, peregrine falcon, flammulated owl, Townsends big-eared bat, common loon, northern bog 
lemming, Columbian sharp-tailed grouse, Coeurd' Alene salamander, mountain plover, and harlequin duck. See Attachment $\mathrm{C}$ for detailed effects assessments to species that might be affected.

\section{HISTORICAL AND ARCHAEOLOGICAL SITES:}

Identify and determine effects to historical, archaeological or paleontological resources.

Two surface stone features (24LC857) have been identified on the tract but are outside the areas of potential effect. No additional cultural concerns have been identified. No negative effects are expected to occur as a result of the proposed project.

\section{AESTHETICS:}

Determine if the project is located on a prominent topographic feature, or may be visible from populated or scenic areas. What level of noise, light or visual change would be produced? Identify cumulative effects to aesthetics.

The project is not located near any heavily populated or scenic areas, however the overstory removal harvest unit can be seen at a distance from Highway 200 and from several residences in the area. This unit is currently a shelterwood unit that is fairly open and the removal of the overstory trees is expected to cause very little negative aesthetic effects from these distant locations. The established regeneration is beginning to fill in and in the future will give the stand a more heavily forested look. No additional negative effects are expected to occur as a result of the proposed project.

\section{DEMANDS ON ENVIRONMENTAL RESOURCES OF LAND, WATER, AIR OR ENERGY:}

Determine the amount of limited resources the project would require. Identify other activities nearby that the project would affect. Identify cumulative effects to environmental resources.

No negative effects are expected to occur as a result of the proposed project.

\section{OTHER ENVIRONMENTAL DOCUMENTS PERTINENT TO THE AREA:}

List other studies, plans or projects on this tract. Determine cumulative impacts likely to occur as a result of current private, state or federal actions in the analysis area, and from future proposed state actions in the analysis area that are under MEPA review (scoped) or permitting review by any state agency.

State Forest Land Management Plan EIS, DNRC 1996, set the strategy that guides DNRC management decisions statewide.

Star Val Road Timber Permit, DNRC 2004, salvage of 500 bdft from lease lot in Section 16, T14N, R8W.

Lincoln Flats Precommercial Thinning EA Checklist, DNRC 2004, precommerically thin 127 acres in Section 16, T14N, R8W.

McDonald Gold Project EIS, Seven-Up Pete Joint Venture 1994, construction of a gold mine and removal of gold and associated activities on Section 6 T14N, R7W.

Golden Arches EA, DNRC 2004, harvest of 5.6 MMBF in the Landers Fork drainage.

Cool Flat 4X4 EA, DNRC 2005, harvest of 1.5 MMBF on Sections 8, 16, 19, and 22 of T14N, R8W.

ABC EA, Scoped by DNRC in January of 2006, harvest 4.2 MMBF on Sections 2, 10, 12, 16, and 18 of T15N, $7 \mathrm{~W}$.

Lincoln Compound II Categorical Exclusion, FS 2003, harvest 155 MBF from 34 acres in Section 19 T14N, R8W.

Snow Talon Burned Area Emergency Rehabilitation Plan, FS 2003, assesses post-fire conditions.

Helena National Forest Weed EIS, FS 2004, proposes weed control on FS ground in the Lincoln area. 
Lincoln Post-Fire Rehabilitation Project Categorical Exclusion, FS 2004, proposal to address non-emergency fire rehabilitation needs within the Snow Talon and Moose Wasson burned areas such as tree and shrub plantings, biological weed control, insect monitoring, pesticide, and pheromone treatments, and administrative site maintenance and repair.

Snow Talon Fire Salvage Draft EIS, FS 2005, proposal to salvage approximately 20-25 MMBF on up to approximately 2700 burned acres and associated activities and reclamation of 105 acres of old jammer trails all in the Copper Creek drainage and associated haul road in the Landers Fork and Copper Creek drainage.

See the cumulative effects analysis found in other sections of this EA for associated effects to resources.

\section{IMPACTS ON THE HUMAN POPULATION}

- RESOURCES potentially impacted are listed on the form, followed by common issues that would be considered.

- Explain POTENTIAL IMPACTS AND MITIGATIONS following each resource heading.

- Enter "NONE" If no impacts are identified or the resource is not present.

\section{HUMAN HEALTH AND SAFETY:}

Identify any health and safety risks posed by the project.

Log trucks would be hauling products from the site and would need to be watchful of the public. Should any activities take place in the winter months, DNRC would work with the local snowmobile club to minimize effects and safety hazards on their trail system. No additional negative effects are expected to occur as a result of the proposed project.

\section{INDUSTRIAL, COMMERCIAL AND AGRICULTURE ACTIVITIES AND PRODUCTION:}

Identify how the project would add to or alter these activities.

People are currently employed in the wood products industry in the region. Due to the relatively small size of the timber sale program, there would be no measurable effects or cumulative impact from this proposed action on industrial, commercial and agricultural activities and production.

\section{QUANTITY AND DISTRIBUTION OF EMPLOYMENT:}

Estimate the number of jobs the project would create, move or eliminate. Identify cumulative effects to the employment market.

People are currently employed in the wood products industry in the region. Due to the relatively small size of the timber sale program, there would be no measurable effects or cumulative impact from this proposed action on employment.

\section{LOCAL AND STATE TAX BASE AND TAX REVENUES:}

Estimate tax revenue the project would create or eliminate. Identify cumulative effects to taxes and revenue.

People are currently paying taxes from the wood products industry in the region. Due to the relatively small size of the timber sale program, there would be no measurable effects or cumulative impact from this proposed action on tax revenues.

\section{DEMAND FOR GOVERNMENT SERVICES:}

Estimate increases in traffic and changes to traffic patterns. What changes would be needed to fire protection, police, schools, etc.? Identify cumulative effects of this and other projects on government services

There would be no measurable effects or cumulative impacts related to demand for government services due to the relatively small size of the timber sale program, the short-term impacts to traffic, and the small possibility of a few people temporarily relocating to the area. 


\section{LOCALLY ADOPTED ENVIRONMENTAL PLANS AND GOALS:}

List State, County, City, USFS, BLM, Tribal, and other zoning or management plans, and identify how they would affect this project.

In June 1996, DNRC began a phased-in implementation of the State Forest Land Management Plan (Plan) and the State Forest Land Management Rules (Rules) followed. The management direction provided in the Plan comprises the framework within which specific project planning and activities take place. The Rules and Plan philosophy and appropriate Resource Management Standards have been incorporated into the design of the proposed action.

\section{ACCESS TO AND QUALITY OF RECREATIONAL AND WILDERNESS ACTIVITIES:}

Identify any wilderness or recreational areas nearby or access routes through this tract. Determine the effects of the project on recreational potential within the tract. Identify cumulative effects to recreational and wilderness activities.

This tract and the project area are used by the public primarily for hunting, firewooding, 4-wheeling, and snowmobiling. All of the roads in this tract are open to motorized use except in the winter when they are closed to snowmobiles by an agreement between the local snowmobile club and the Montana Department of Fish, Wildlife, and Parks except for a designated route in the very southeast corner of the section. Additionally, most of the roads surrounding this section are open to motorized use year round.

While the approximately 0.5 miles of new roads constructed as part of this proposal would be gated and an additional 0.5 miles would be closed (those spurs that connect the new road construction back to the main road system would be gated and the road on the west edge of the overstory removal unit would be closed with an earth berm) as well, this construction and closures are not expected to have any measurable effects to recreational activities in this tract or within the area.

\section{DENSITY AND DISTRIBUTION OF POPULATION AND HOUSING:}

Estimate population changes and additional housing the project would require. Identify cumulative effects to population and housing.

There would be no measurable cumulative impacts related to population and housing due to relatively small size of the timber sale program, and the fact that people are already employed in this occupation in the region.

\section{SOCIAL STRUCTURES AND MORES:}

Identify potential disruption of native or traditional lifestyles or communities.

No negative effects are expected to occur as a result of the proposed project.

\section{CULTURAL UNIQUENESS AND DIVERSITY:}

How would the action affect any unique quality of the area?

No negative effects are expected to occur as a result of the proposed project.

\section{OTHER APPROPRIATE SOCIAL AND ECONOMIC CIRCUMSTANCES:}

Estimate the return to the trust. Include appropriate economic analysis. Identify potential future uses for the analysis area other than existing management. Identify cumulative economic and social effects likely to occur as a result of the proposed action.

The proposed activities would generate approximately $\$ 319,800$ for the Public Building Trust Grant. See Attachment $\mathrm{E}$ for a more detailed analysis.

\begin{tabular}{l|lll} 
EA Checklist & Name: & Steve Kamps & Date: 2/28/06 \\
Prepared By: & Title: & Forest Management Specialist & \\
\hline
\end{tabular}




\section{FINDING}

\section{ALTERNATIVE SELECTED:}

Action Alternative B.

26. SIGNIFICANCE OF POTENTIAL IMPACTS:

See Finding found after the cover page.

\section{NEED FOR FURTHER ENVIRONMENTAL ANALYSIS:}

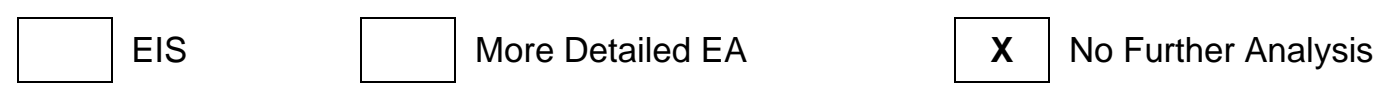

\begin{tabular}{|l|ll}
\hline EA Checklist & Name: & Craig V. Nelson \\
\cline { 2 - 3 } Approved By: & Title: & Supervisory Forester \\
\hline
\end{tabular}

Signature: /s/ Craig V. Nelson

Date: March 9, 2006 


\section{Attachment A Maps}




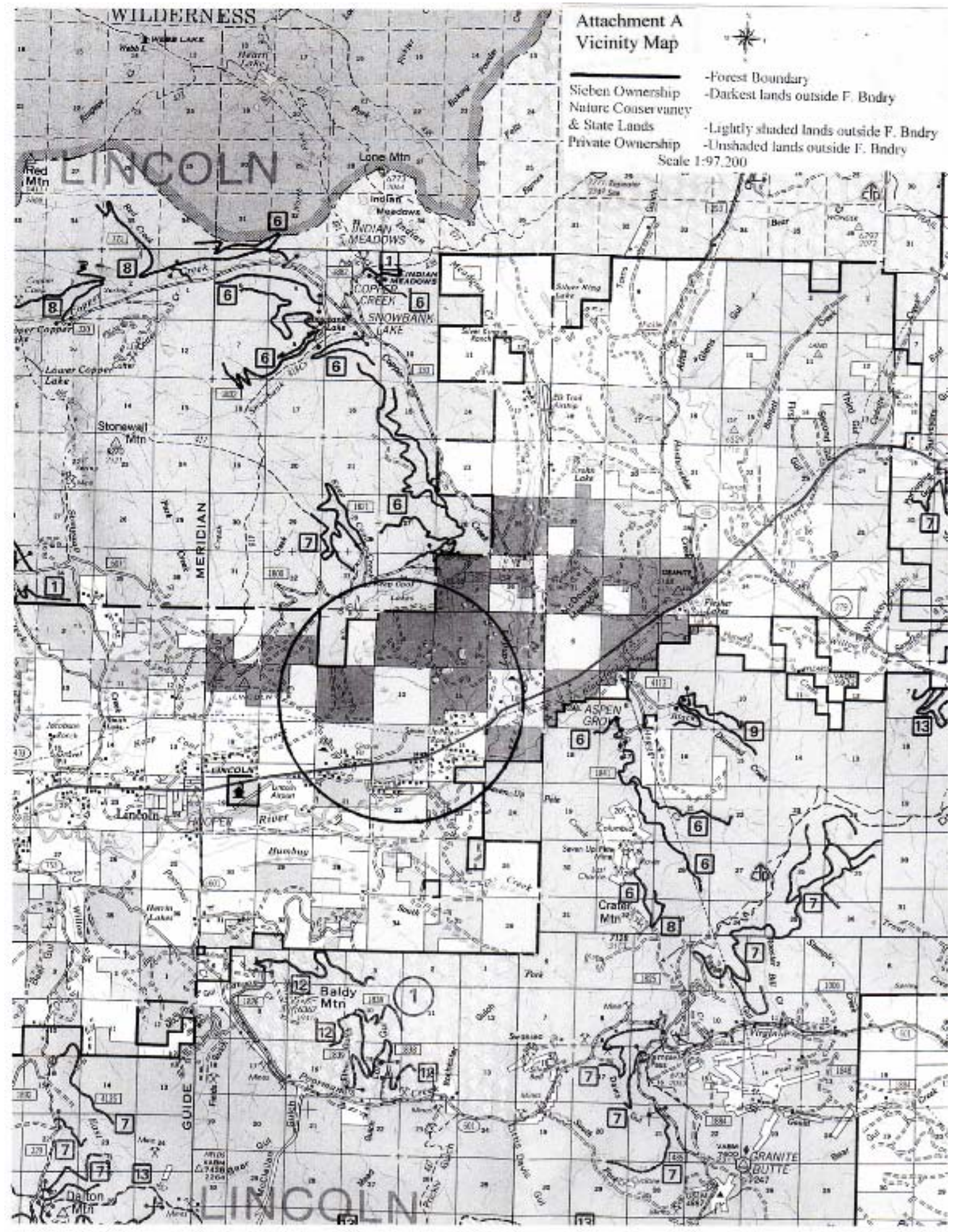




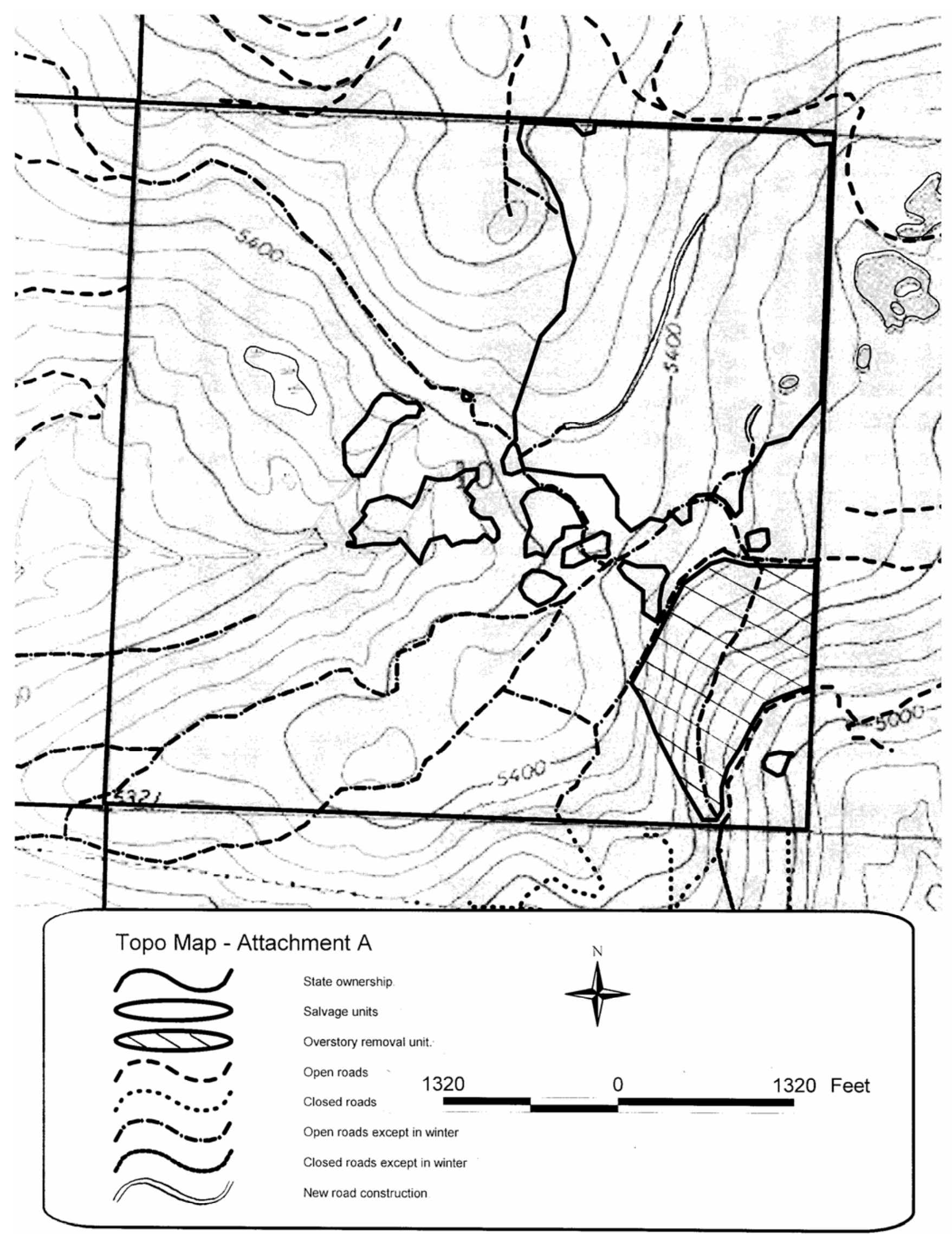




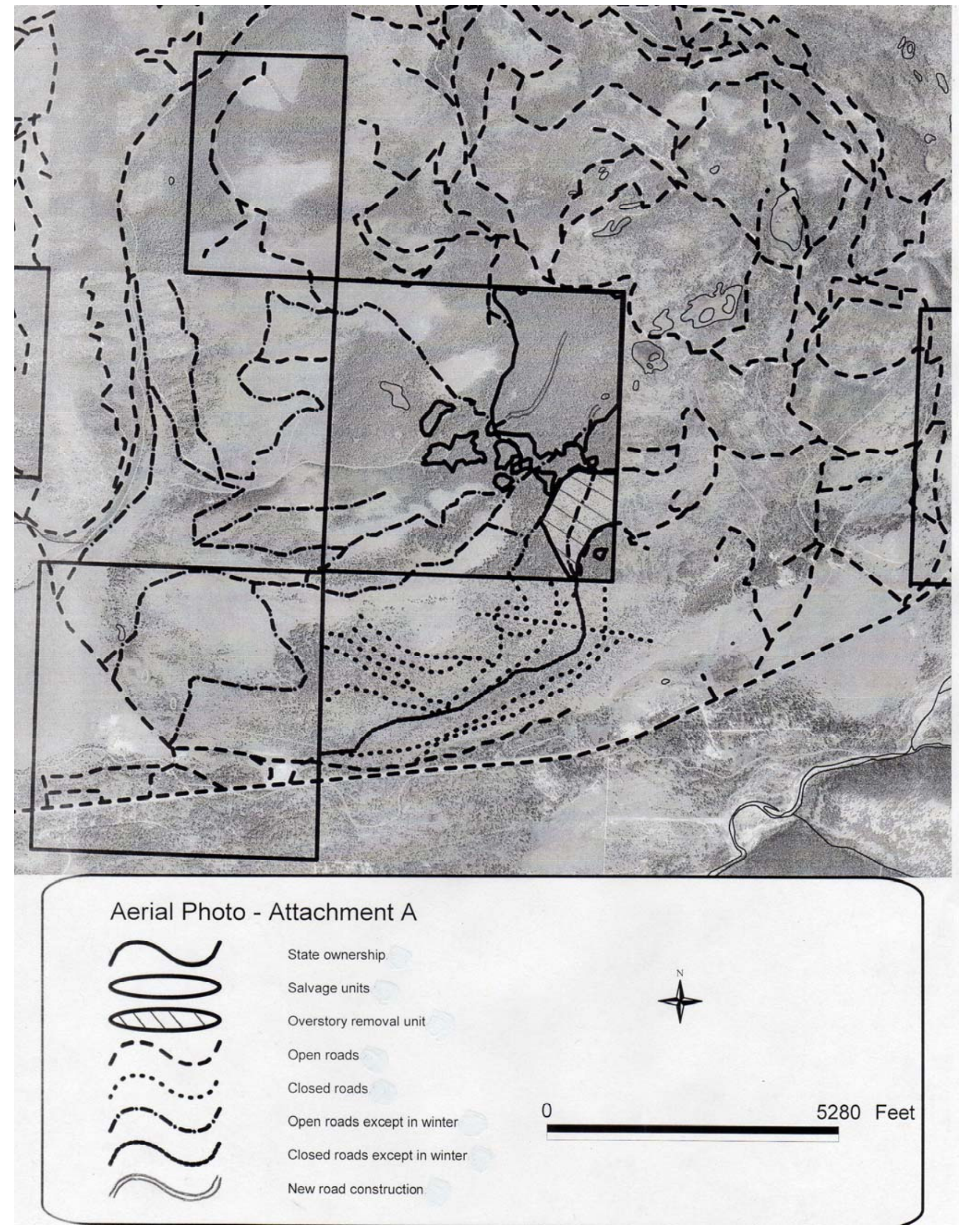




\section{Attachment B \\ Vegetative Resources}




\section{Vegetative Resources}

\section{General Description of the Area}

The proposed Keep Cool Bugs Timber Sale is located in the western foothills of the Continental Divide, northeast of Lincoln, MT. Elevations in the harvest area vary between 5000 and 5600 feet. These parcels drain to tributaries of the Blackfoot River. The trust lands involved in the proposed project are mostly forested but are leased for grazing. Past management activities include a timber sale in approximately 1989 with some follow-up blowdown salvage on approximately 140 acres that resulted in some clearcut to shelterwood type harvest units. Also in 2005 a 2 acre post and pole sale was conducted on the northern boundary of the section.

During the fire season of 2003 approximately 37,700 acres burned as part of the Snow Talon Fire in the upper reaches of Copper Creek and the Landers Fork and surrounding drainages with primarily high intensity stand replacing fires. This fire lies north of the project area and burned to within approximately three miles of state ownership in Section 10.

The forested areas on state ownership within the project area are comprised primarily of Douglas-fir and lodgepole pine. The forested habitat types present are primarily PSME/VACA and ABLA/VACA (Pfister et.al., 1977). These stands are generally double and single-storied with the overstories being approximately 80-150 years old except a few 15 year old young stands created from past harvesting. Regeneration and sapling size trees are common within these stands, however most are in poor health due to overstocking.

Historical fire frequencies for the warm moist Douglas-fir fire group have a mean fire interval of approximately 42 years and the cool fire group has a severe fire interval of approximately less than 100 years to 500 years (Fischer and Bradley, 1987).

The trust lands involved in the proposed sale area total approximately 640 acres with approximately 601 acres of forested ground. General stand vigor ranges from poor to good with the majority of the area being in the fair category. Insect activity is currently present in most of the stands in low to high amounts.

\section{Cumulative Impacts of Past Forest Management Activities}

Past harvesting has occurred within this section as well as those state sections adjacent to Section 10 and most of the adjacent private and Forest Service land.

Past harvesting in Sections 4 and 10 consisted of approximately 235 acres of regeneration type harvests in approximately 1989. Regeneration in the units ranges from poor to good. Past harvesting in Section 16 has been primarily selective with more selective harvesting planned as part of the Cool Flat 4X4 Timber Sale. Most of this past harvesting occurred over 30 years ago. The past selective harvesting has removed primarily larger trees however some large trees remain, while the planned selective harvesting will remove primarily smaller trees and leave the healthier larger trees. Harvesting has created room for younger age classes. 
All of the sections have old road systems utilized in past harvesting and all have received moderate to high levels of firewooding as is evidenced by the scattered stumps of dead trees that were removed. Some less accessible areas still have high amounts of dead standing and down trees while the more accessible areas have primarily been picked clean.

Timber harvesting has taken place on a majority of the surrounding private lands (see Attachment A, Aerial Photo). In general, the area surrounding the state ownership has been more heavily harvested in the past 40 years than state ownership. Most of this harvesting has been by means of high-grading, group selections and some selective harvesting. Most of the harvesting is over 15 years old and is fully regenerated with good stocking levels, although Section 15 just south of state Section 10 was highgraded approximately 10 years ago and is still quite open. Harvesting on these surrounding private lands is expected to continue over time, however to a lesser extent than in the past since a majority of the ground has already been heavily harvested. Sieben Livestock Company is currently logging in Section 2 northeast of Section 10 and are expected to continue to log, likely in the winter months in Sections 2, 3, and 35 in the next few years.

There is good public access to all of Section 10 although in the winter it is closed to snowmobiling except for a short segment of trail in the southeast corner of the section. Major past and present uses of the proposed project area are recreation, grazing, timber production, and mineral exploration.

\section{Vegetative Affected Environment}

For the vegetative related resources, the cumulative effects analysis area includes Section 10 and all those lands within one mile of this section. This involves and includes both private and federal ownership in addition to state ownership (see Attachment A, Vicinity map).

\section{Forest Structure and Cover Types}

\section{Regional and Unit-wide Assessments}

At the broad scale, assessments prepared for the 1997 Interior Columbia River Basin (ICRB) Draft EIS are useful in examining how DNRC's ownership fits into the larger ecosystem. The information in the ICRB Draft EIS shows the general trend across the analysis area is a decrease of ponderosa pine, western larch, and western white pine across their ranges. The primary trend is from shade intolerant to more shade tolerant species (true firs, spruces, and western red cedar) with the shade intolerant species (ponderosa pine, lodgepole pine, and western larch) out competed and replaced by shade tolerant species. Fire regimes have changed from predominantly mixed and non-lethal severity to a large predominance of lethal severity fires. Acres of old forests of both multistory and single story structure have decreased.

The ICRB EIS grouped forests into three broad categories:

Dry - includes ponderosa pine, dry Douglas-fir, and dry grand fir forests.

Moist - includes cedar/hemlock, moist Douglas-fir, grand fir, and wet spruce/fir forests. 
Cold - includes the higher elevation forests not falling into 1 of the other 2 categories.

All three forest groups have experienced large increases in dominance by shade-tolerant species due to timber harvesting, fire suppression, insects, and diseases. All 3 groups are more likely to experience stand replacing fires than they did historically due to a large buildup of fuels and changes in stand structure and composition. The majority of the stands in the proposed project area would fall in the Moist and Cool forest category.

An overall decrease in old growth stands has occurred in the dry forest group with a large increase in multistoried stand conditions and a large decrease in single storied forests. Within the multistoried forests, shade tolerant tree species are 3 times as abundant. Ponderosa pine has been replaced by grand fir or Douglas-fir on nearly $40 \%$ of its range. Shade tolerant species dominate $30 \%$ more stands than historically. Many of the trends summarized above are taking place in the proposed project area.

Estimating historical conditions is important in defining what the forest looked like before the widespread settlement and influence of the western Europeans (pre-industrial age). The working assumption is that average historical conditions represent a healthy, sustainable, diverse forest with all the pieces intact as committed to in the SFLMR. Historical conditions provide an indication of a desirable future condition for the forest tempered by current circumstances. Appropriate conditions are based on ecological characteristics (land type, habitat type, disturbance regime, unique characteristics) and can be characterized by the proportion and distribution of forest types and structures historically present on the landscape.

Past management activities and fire suppression appear to have had some effect on shifting cover types on Clearwater Unit. A majority of the current cover types are the same as what would be considered historical (appropriate) cover types under natural processes (Table B-1). 5816 acres of current cover type is different from the appropriate type, which is $12.6 \%$ of the total acres Unit-wide. The majority of the stands that are not in the appropriate cover type fall within the WL/DF type primarily because these stands are more dependent on fire or proper management and are more susceptible to encroachment by other species.

Table B-1

Area by Cover Type and Appropriate Cover Type for Clearwater Unit

\begin{tabular}{|c|c|c|c|c|c|c|c|c|}
\hline \multirow{2}{*}{$\begin{array}{l}\text { Current } \\
\text { Cover } \\
\text { Type }^{1}\end{array}$} & \multicolumn{8}{|c|}{ Appropriate Type } \\
\hline & $\begin{array}{l}\text { ALP/NC } \\
\text { Acres }\end{array}$ & $\begin{array}{l}\text { DF } \\
\text { Acres }\end{array}$ & $\begin{array}{l}\text { HW } \\
\text { Acres }\end{array}$ & $\begin{array}{l}\text { LP } \\
\text { Acres }\end{array}$ & $\begin{array}{l}\text { MC } \\
\text { Acres }\end{array}$ & $\begin{array}{l}\text { PP } \\
\text { Acres }\end{array}$ & $\begin{array}{l}\text { WL/DF } \\
\text { Acres }\end{array}$ & $\begin{array}{l}\text { Total } \\
\text { Acres }\end{array}$ \\
\hline ALP & 353 & 167 & & 285 & & & 1909 & 2714 \\
\hline DF & & 5844 & & & & & 291 & 6135 \\
\hline HW & & & 176 & & & & & 176 \\
\hline LP & & & & 4122 & & 16 & 895 & 5033 \\
\hline MC & & 284 & & 165 & 458 & & 1337 & 2244 \\
\hline $\mathbf{P P}$ & & & & & & 16,455 & 36 & 16,491 \\
\hline WL/DF & & 293 & & & & 138 & 12,900 & 13,331 \\
\hline Total & 353 & 6588 & 176 & 4572 & 458 & 16,609 & 17,368 & 46,124 \\
\hline
\end{tabular}

${ }^{1}$ ALP = Alpine Fir, HW = Hardwood (Cottonwood, Aspen) PP = Ponderosa Pine, DF = Douglas-fir, WL-DF = Western Larch-Douglas-fir, $\mathbf{L P}=$ Lodgepole Pine, $M C=$ Mixed Conifer. 
Note: These figures were computed using current data as of January 1, 2004.

Clearwater Unit is currently dominated by PP and WL-DF cover types (36\% and 29\% respectively), which are also the dominant appropriate types. This indicates that Clearwater Unit has a variety of lower elevation dry types as well as more moist higher elevation types with a distribution of cover types in between.

Table B-2 lists Unit-wide age class distribution by cover type. Stand age has been influenced by fire suppression as well. This lack of moderate severity and stand replacement fires has been a primary cause in the shift in age classes from the younger seedling/sapling stages to the more mature age classes. Historically in this region, an average of cover types within the respective age classes would be $23 \%$ in seed-sapling, $29 \%$ in poles, $21 \%$ in mature, and 21\% in older age classes (Losensky, 1997).

Table B-2

Current Age Structure by Current Forest Cover Types for Clearwater Unit

\begin{tabular}{|l|l|l|l|l|l||}
\hline $\begin{array}{l}\text { Cover } \\
\text { Type }\end{array}$ & $\begin{array}{l}\text { Seed-Sapling } \\
\mathbf{1 - 3 9} \text { yrs }\end{array}$ & \multicolumn{1}{|c|}{$\begin{array}{c}\text { Poles } \\
\mathbf{4 0 - 9 9} \text { yrs }\end{array}$} & $\begin{array}{c}\text { Mature } \\
\mathbf{1 0 0 - 1 4 9} \text { yrs }\end{array}$ & $\begin{array}{c}\text { Older } \\
\mathbf{1 5 0 +} \text { yrs }\end{array}$ & $\begin{array}{l}\text { Total } \\
\text { Acres }\end{array}$ \\
\hline \hline PP & $\mathbf{9 5 4}$ & $\mathbf{4 7 2 5}$ & $\mathbf{7 0 7 2}$ & $\mathbf{3 7 4 0}$ & 16,491 \\
\hline \hline DF & $\mathbf{3 0 7}$ & $\mathbf{1 1 8 7}$ & $\mathbf{2 7 7 6}$ & $\mathbf{1 8 6 5}$ & 6135 \\
\hline $\begin{array}{l}\text { WL- } \\
\text { DF }\end{array}$ & $\mathbf{2 1 9}$ & $\mathbf{2 7 7 4}$ & $\mathbf{5 3 2 8}$ & $\mathbf{5 0 1 0}$ & 13,331 \\
\hline LP & $\mathbf{5 9 1}$ & $\mathbf{2 7 7 3}$ & $\mathbf{1 3 3 1}$ & $\mathbf{3 3 8}$ & 5033 \\
\hline MC & $\mathbf{8 1}$ & $\mathbf{7 8 9}$ & $\mathbf{1 0 7 5}$ & $\mathbf{2 9 9}$ & 2244 \\
\hline ALP & $\mathbf{1 0 6}$ & $\mathbf{6 0 6}$ & $\mathbf{9 1 8}$ & $\mathbf{1 0 8 4}$ & 2714 \\
\hline \hline HW & $\mathbf{0}$ & $\mathbf{1 6 3}$ & $\mathbf{1 3}$ & $\mathbf{0}$ & 176 \\
\hline \hline Total ac & $2258(5 \%)$ & $13,017(28 \%)$ & $18,513(40 \%)$ & $12,336(27 \%)$ & 46,124 \\
\hline \hline
\end{tabular}

Note: These figures were computed using current data as of January 1, 2004.

\section{Project Level Analysis}

Within the proposed sale area approximately 131 acres have a different current cover type than the appropriate cover type. This is well above the unit average of $12.6 \%$ that do not have the same cover types.

On state ownership in the analysis area the predominant stand type is Douglas-fir followed closely by ponderosa pine (Table B-3), which is somewhat different from the unit averages found above. The age trends are somewhat similar to the unit-wide (Table B-2) averages especially in the mature age classes. There is however a $20 \%$ difference in the seed-sap age class and a $20 \%$ difference in the older age class. Most of the trends affecting the ICRB are also similar to those of the analysis area.

Table B-3

Current Age Distribution by Cover Type in the Analysis Area On State Land 


\begin{tabular}{|c|c||c|c|c|c|c|c|}
\hline $\begin{array}{c}\text { Cover } \\
\text { Type }\end{array}$ & $\begin{array}{c}\text { Non- } \\
\text { Stocked }\end{array}$ & $\begin{array}{c}\text { Seed- } \\
\text { Sap } \\
\mathbf{1 - 3 9} \\
\text { Acres }\end{array}$ & $\begin{array}{c}\text { Poles } \\
\mathbf{4 0 - 9 9} \\
\text { Acres }\end{array}$ & $\begin{array}{c}\text { Mature } \\
\mathbf{1 0 0 - 1 4 9} \\
\text { Acres }\end{array}$ & $\begin{array}{c}\text { Older } \\
\mathbf{1 5 0 +} \\
\text { Acres }\end{array}$ & $\begin{array}{c}\text { Non- } \\
\text { Foreste } \\
\text { d } \\
\text { Acres }\end{array}$ & $\begin{array}{c}\text { Total } \\
\text { Acres }\end{array}$ \\
\hline PP & & $\mathbf{1 7 6}$ & $\mathbf{1 6 6}$ & $\mathbf{1 1 3}$ & $\mathbf{4}$ & & 459 \\
\hline DF & & $\mathbf{5 2}$ & & $\mathbf{4 7 7}$ & $\mathbf{9 1}$ & & 620 \\
\hline $\begin{array}{c}\text { WL- } \\
\text { DF }\end{array}$ & & & & $\mathbf{1 9}$ & & & 19 \\
\hline LP & & $\mathbf{1 1 5}$ & $\mathbf{3 0}$ & & & & 145 \\
\hline MC & & & $\mathbf{7 2}$ & & & & 72 \\
\hline ALP & & $\mathbf{1 0}$ & $\mathbf{8}$ & $\mathbf{2 2}$ & & & 40 \\
\hline NS* & $\mathbf{1 0}$ & & & & & & 20 \\
\hline NF* & & & & & & $\mathbf{1 5 2}$ & 152 \\
\hline Total & $10(1 \%)$ & $353(25 \%)$ & $276(21 \%)$ & $631(46 \%)$ & $95(7 \%)$ & 152 & 1517 \\
\hline
\end{tabular}

$* \mathrm{NF}=$ nonforested

NS $=$ non-stocked

Almost all of the ponderosa pine cover types are found in Section 16 at the lower elevations. Most of the Douglas-fir and lodgepole cover types are found in Sections 4 and 10. There are two non-stocked stands found in Section 10. One stand in Section 10 is classified at non-stocked because it has not regenerated sufficiently. Approximately 152 acres of grasslands are found primarily in Section 16 and are composed of native grasses, sagebrush, and encroaching trees.

The stands proposed for harvest consist primarily of $45 \%$ Douglas-fir and $55 \%$ lodgepole pine with a few scattered ponderosa pine, spruce, alpine fir, and a couple of western larch. They are all mature sawlogs stands that are approximately 110 years old. Some areas have a higher proportion of Douglasfir while others have almost exclusively lodgepole pine. They are primarily single storied stands although some regeneration primarily in the form of Douglas-fir, alpine fir, and lodgepole pine have become established in the more open areas of the stands. These stands are moderately to well stocked and average 12-16 inches in diameter with average basal areas around 130 square feet. The lodgepole pine are mostly heavily infected with mistletoe and currently have a mountain pine beetle epidemic while the Douglas-fir are primarily in good health and form although Armellaria root rot (Armellaria $s p p$ ) is present in some locations. Overall vigor in these stands is poor due to the condition of the lodgepole pine.

The shelterwood stand that would receive the overstory removal harvest consists of approximately $90 \%$ Douglas-fir and 10\% ponderosa pine. The shelterwood trees are approximately 140 years old with average diameters of 18-22 inches and an average basal area of approximately 40 square feet. Regeneration has become established in the southern 2/3 of the stand both by means of natural regeneration of primarily lodgepole pine and Douglas-fir and planting of ponderosa pine and possibly some Douglas-fir. The northern $1 / 3$ of the stand has a slightly more southerly aspect and has been subjected to browse damage of regeneration. Throughout the unit the regeneration is being somewhat suppressed by the overstory trees that have provided shelter up to this point.

Cumulatively, the stands found on state ownership are in younger age classes than might have been expected historically. Additionally, within the analysis area much of the private land has been 
harvested within the last 30-40 years and also have a higher representation of these younger age classes resulting in an age class structure within the analysis area that is lower than what would have been expected historically. Almost all the stands surrounding state ownership are moderate to well stocked and cover types appear to be appropriate.

\section{Forest Health}

Generally, the overall stand health across State ownership is widely varied from good to poor and is primarily dependent on stocking levels and age. Most of the stands are overstocked, and/or have problems with insects and disease. Generally, the stands that are heavily stocked have poorer rates of growth since growing space, nutrients, water, and sunlight are more limited. Health varies from stand to stand, but the stands with the poorest health are the heavily stocked stands in which the individual tree vigor is declining and where growing space is limited. The best growth rates on these parcels can be found in the younger, thriftier stands of ponderosa pine and in some of the multi-storied stands. There are currently high levels of insect activity on Section 10, and conditions do exist for outbreaks to continue to occur.

Generally the Douglas-fir and ponderosa pine stands are in fair to poor health and are in better health where the younger age classes exist. Overstocking and old age are the primary growth inhibitors in these stands. Many of the older trees have thinning crowns, dead tops, and poor growth rates while the younger trees are relatively healthy and suffer primarily from overstocking and competition. There are low to moderate amounts of Armellaria root rot found in pockets within the Douglas-fir stands in the analysis area. These stands are suffering mortality primarily in the Douglas-fir trees and other infected trees have poorer growth and thinning crowns and are being weakened by the disease. Ponderosa and lodgepole pine are less susceptible to root rot and do not appear to be suffering these same losses. Brown Cubical Butt Rot is also infecting some of the Douglas-fir and is causing rotting and decay of the stem and/or roots of infected trees and are spread by spores of fruiting bodies. This is usually found in the older more decadent stands of Douglas-fir. Additionally, several small pockets of Douglas-fir bark beetles also exist, but do not appear to be rapidly increasing at this time. The densely stocked and multi-storied stands of Douglas-fir could be susceptible to spruce budworm attacks should budworm populations increase in the area. There is currently an outbreak of spruce budworm occurring in the Flesher Pass area 6-8 miles east of the project area. Budworms do not typically kill many of the trees they attack but can cause severe declines in stand health and growth.

Most of the lodgepole pine stands are heavily stocked and have reached maturity. Both of these conditions have led to substantially slowed growth rates in these trees. Many of the individual trees have small, thin crowns that are becoming or are already flat topped. Additionally, mistletoe can be found in most of the lodgepole stands with a range of severities from light to heavily infected. Dwarf mistletoes are widespread throughout the Northern Region and have a great impact on the forests. These parasites are native components of the forest ecosystems in the western United States, but human influences such as partial cutting and fire exclusion have served to increase the intensification, spread, and severity of dwarf mistletoes to unnatural and unmanageable levels in many forest stands (USDA Forest Service R-1, 1991). Some of the trees are so heavily infected that mortality is occurring while others are deformed and rotting from the infections. Trees with lighter infections are suffering growth losses and beginning to show signs of physical deformities as a result of the mistletoe infections. Understory trees are also quickly becoming infected. When infected at a young age, most of these trees will never become large and provide the canopy cover or seed source that their parents 
did. Because of the growth inhibiting effects of mistletoe these young trees would likely remain small, bushy, and misformed. In the most heavily infected areas, total stand growth rates are near zero.

Within the project area mountain pine beetle activity is prevalent in the lodgepole pine and is at epidemic levels within the proposed harvest units. This beetle activity has been present at elevated levels over the past 3-5 years although it has accelerated within the last 2 years and is expected to continue to expand in 2006. Additionally, lower levels of beetle activity can be found outside of the units in stands with lodgepole pine, but the beetles are not at epidemic levels yet. However most of these stands with high proportions of lodgepole pine are currently at a highly susceptible stage for mountain pine beetle attacks. The most susceptible stands are at relatively low elevations, greater than 8 inches in diameter, and older than 80 years of age (USDA Forest Service et. al., 1991). The risk is compounded by the stands being in poor health with low vigor. Most of the lodgepole pine are also infected with mistletoe which is also contributing to the poor health in these stands and predisposing these stands to a higher risk of pine beetle attack. On the other hand, within the proposed harvest units, the Douglas-fir are in relatively good health other than from the effects of competition and where Armellaria root rot is present. There are only a few scattered individuals of ponderosa pine, spruce, alpine fir, and western larch within the proposed harvest area.

Within the analysis area on surrounding ownership stand health tends to be better since most of the stands have been managed in the last 40 years and are now in the younger age classes. Some of the stands are to the point where they are becoming densely stocked and competition is beginning to slow growth rates however.

The near exclusion of fire in the $20^{\text {th }}$ century has likely affected many of the currently overstocked stands in the analysis area. The ponderosa pine stands would have been expected to receive frequent low intensity fires that would burn many of the understory Douglas-fir and pine and maintain these stands at lower stocking levels than exist today which would have resulted in more healthy and vigorous stands. The Douglas-fir stands would have been expected to receive less frequent but moderate intensity fires that also would have had beneficial thinning effects that would improve forest health.

\section{Fire Hazard}

The most predominant historic fire frequencies in the project area are the moist Douglas-fir habitat types and the cool habitat types, which had a mean fire interval of around 42 years and a severe fire expectancy of less than 100 - 500 years respectively in pre-settlement stands. Fire was an important agent in controlling density and species composition. Low to moderate severity fires converted dense stands of pole-sized or larger trees to a more open condition, and subsequent light burning maintained stands in a park-like state. Frequent low or moderate fires favored larch and ponderosa pine over Douglas-fir in stands where these species occurred. Severe fires probably occurred on dense, fuelheavy sites and resulted in stand replacement. Stand replacement fires favored lodgepole pine on sites where this species was present (Fischer and Bradley, 1987). In the ponderosa pine dominated stands the fire frequency is expected to be shorter between fires and was typically a lower intensity event except in areas where fuels had built up.

Currently, the risk of a stand replacing fire or a fire that would burn more intensely than expected under natural conditions historically on these three sections is moderate. With the near exclusion of fire in the $20^{\text {th }}$ century, stand dynamics, succession, and fuel loadings have all changed. With 
increased fuel accumulations on the forest floor, stand densities, and amounts of ladder fuels (especially Douglas-fir in the understory) in these stands, fires burning today are much more likely to be more intense. These more intense fires tend to replace entire stands that would not have typically been replaced historically often times with negative effects of soil damage, species composition changes, difficulty regenerating the site, and sometimes very unnatural conditions for entire drainages from those of historic conditions.

The near exclusion of fire in the $20^{\text {th }}$ century has likely affected many of the currently overstocked stands in the analysis area. Stand dynamics, succession, and fuel loadings have all changed over the past 100 years to create a situation that puts these forest stands at a much higher risk of high intensity and sometimes stand replacing fires. Past harvesting of trees has helped decrease fuel loadings and stand densities, but in many cases has removed the larger trees that are in most cases more fire resistant. Within the analysis area, fire hazard has generally increased over time in the ways described above with the exception of the more recently harvested areas which are primarily on the adjacent private lands. In these locations, the risk of high intensity fires is still low to moderate due to decreased stocking levels, amounts of mistletoe, and ladder fuels.

\section{Old Growth}

There are 95 acres of stands classified as older in the analysis area on state ownership, however, none of these stands meet the Green et al. definition of old growth that has been adopted by the DNRC. Most of these acres (91) are Douglas-fir cover type and the remainder of acres are in the ponderosa pine cover type resulting in 7 percent of the state ownership on the project area being classified as older.

While other stands in the analysis area do contain scattered old trees, none are sufficient enough in numbers to qualify the stands as older.

Within the analysis area the near exclusion of fire would have likely increased the amount and distribution of old growth, however heavy past harvest activity on adjacent private lands has likely resulted in a net decrease in the amount of old growth that might have been expected on the landscape historically. Some old growth stands may exist within the analysis area on Forest Service ground.

\section{Sensitive Plants}

A search of the Montana Natural Heritage Program was conducted and no sensitive plants were identified in the analysis area. No sensitive plants have been identified in field reconnaissance by DNRC personnel.

\section{Noxious Weeds}

Noxious weeds occurring in this analysis area are mostly spotted knapweed and spot infestations of Canadian thistle. One of the largest and heaviest infestations of spotted knapweed in the Lincoln area occurs in the analysis area on state and private ownership located south and southwest of Section 10. Knapweed occurs across most of Sections 16 and can be found in the regeneration units in Sections 4 and 10. The main roads within the analysis area get sprayed most years for knapweed. Biological control has recently been used in an attempt to reduce infestations of knapweed as well as decades of herbicide treatments for knapweed. 
These species of weeds are all non-native to the area and were introduced by humans and human activities primarily associated with ground disturbance. Past activities such as road construction, logging, powerline construction, and grazing are likely to have increased the occurrence and spread of these species of weeds in the area.

\section{Potential Effects to Vegetative Resources}

For the vegetative related resources, the cumulative effects analysis area includes Section 10 and all those lands within one mile of this section. This involves and includes both private and federal ownership in addition to state ownership (see Attachment A, Vicinity map). Most of the conclusions that are arrived at in the following section are as a result of professional judgment and experience.

\section{Forest Structure and Cover Types}

\section{Alternative A}

The stands would not be harvested and the lodgepole would continue to be killed by mountain pine beetle and suffer growth losses from mistletoe. The risk of the beetle epidemic spreading on to adjacent ownerships and continuing to kill lodgepole pine and change stockings, species distributions and cover would be high. Additionally, other parts of the stands would be changed slowly by successional processes. The stands would continue to age and trees would grow larger. An increase in stem rot, mistletoe, and other infectious agents would be expected as would increased amounts of down woody debris. The already overstocked stand conditions would continue and worsen with the exception of those areas where openings are created from mortality from mountain pine beetles. In these areas the initiation of new growth might be expected. There would be an increased risk of largescale loss to fire over time.

\section{Alternative B}

Under the action alternative, age class distribution, average tree size, and tree spacing would all be affected. In general, age class distribution within the proposed harvest units would be changed toward a younger distribution as growing space is created and regeneration is initiated. The harvested stands would likely be re-delineated into new stands that would differentiate between those areas that have higher amounts of Douglas-fir remaining post-harvest and those that have very little residual trees remaining. This would result in some of the harvested acres remaining as mature forest where enough Douglas-fir are present for the age class to remain unchanged. It would also result in some acres being reclassified as seedling/sapling stands where very few overstory trees remained and where regeneration would start a new age class. The unit receiving the overstory removal would be changed from a mature stand to a seedling/sapling stand with the removal of most of the overstory. Additionally, with the successful planting of the nonstocked stand near the center of the section, that stand would be changed over time to the seedling/sapling age class.

Those stands that do change in age class would also have a smaller average tree size, although the residual trees would generally be larger in diameter than the smaller lodgepole pine trees that would be removed, the initiation of regeneration would bring the average tree size down. In all cases, the stands 
would be more openly spaced as trees are harvested. Those areas where more Douglas-fir existed and were therefore left would be moderately to heavily stocked with those remaining sawtimber sized trees while those areas with few Douglas-fir existing post-harvest would be more openly spaced with residual sawlog sized trees. Post-harvest the salvaged stands would consist almost exclusively of Douglas-fir with a few scattered ponderosa pine and western larch. The stands would range from a light to heavy stocking of residual trees with most of the area resembling a seedtree or shelterwood type harvest. Residual tree diameters would remain about the same at approximately 12-16 inches on average with basal areas (BA) averaging around 50 square feet post-harvest. Should blowdown of the remaining residual trees occur, these stockings and spacings would be decreased. The proposed harvesting would create two-storied stands over time as regeneration becomes established in the understory of the residual trees. In those areas were very few overstory trees remain with many new trees becoming established in the understory, the stands would in most cases more closely resemble a one-storied stand.

So the average ages found in Table B3 would shift slightly to the younger age classes with a reduction in the amount of stands in the mature age class and an increase in the amount of stands found in the seedling/sapling age class. The older age class would remain the same as none of these stands are proposed for harvest.

Most cover types are not expected to change as a result of the silvicultural prescriptions proposed for these timber stands, however some portions of stands may be reclassified with new cover types due to harvest in a portion of a stand and no harvest in the other, from misclassification, and from redelineation etc.

Section 10 has had blowdown problems in the past. Some of the harvesting that occurred in 1989 were shelterwood type harvests and most of the residual trees blew down in some of the units while other units did not. Because of its location in the Blackfoot Valley, the alignment of the prevailing winds in relation to the section, and some shallow soils, the entire section is at moderate risk to blowdown once harvesting has occurred and those harvested units that occur on ridges and are exposed more to the west winds and have more shallow soils are at high risk to blowdown. Trees most susceptible to blowdown are typically those that are larger with bigger crowns and those that are shallow rooted such as spruce and lodgepole pine, however blowdown of Douglas-fir in the area is also quite common and in fact is what blew down after past harvesting. A moderate amount of blowdown could be expected in the residual stand post-harvest on the project area although a low amount of blowdown is most likely due to the sheltering of the larger unit by a ridge line. Blowdown is most likely to occur in the more open areas of the stands where the largest changes in stand structure would occur and on edges of these units where the wind could pick up speed in the more open areas and hit the more dense edges of unharvested stands with greater force than the trees are currently being exposed to. The majority of the blowdown that could occur as a result of the proposed project would be expected within the first several years following harvesting. After the first several years, the residual trees tend to expand their root systems with the new-found growing space as a result of the thinning effects of harvesting and become more root-firm over time. Should blowdown occur, the residual stands could be somewhat more open than proposed in the action alternative, and this blowdown would likely be salvaged in subsequent years.

The following is a summary of the silvicultural prescriptions and treatments that would influence the structures of the stands in the harvested portions of the project area. See the maps found within this EA to aid in understanding harvest unit size, shape, and location. 
Salvage Harvest: This prescription is designed to salvage dead and dying lodgepole pine as well as the remaining lodgepole pine that are not beetle hit that are at high risk of being killed and/or are infected with mistletoe while maintaining good ponderosa pine and Douglas-fir to continue to grow and regenerate within the stands. All merchantable lodgepole pine within the units would be cut as well as possibly lodgepole that are pulp sized unless they are larger culls with woodpecker cavities that might make a good snag in which case the tree may be girdled if infected with mistletoe. Cutting most of the lodgepole trees with mistletoe would serve to reduce the current amounts of mistletoe and minimize its spread into the residual and adjacent stands. Most large standing dead trees will be left as snags where safe to do so. Additionally, all of the few merchantable and pulp sized alpine fir that are encountered would be cut and the few spruce that are encountered would be cut due to their tendency to blow down. The current occurrence and distribution of healthy ponderosa pine and Douglas-fir within the stands is uneven which will tend to leave an irregular spacing of these residual trees. Large openings with no leave trees up to approximately 5 acres in size are expected as are some areas with very few trees removed. This will result in a mosaic of heavily and moderately stocked areas that are predominantly Douglas-fir to areas that resemble shelterwood, seedtree and group selections as patch clearcuts where less Douglas-fir are present. Average basal areas within the stands should be around approximately 50 square feet immediately post-harvest and will be very unevenly spaced. Based on past history with cutting units in this section, the risk of blowdown within and adjacent to the units is high. Advanced regeneration other than alpine fir and healthy submerchantable trees will be protected. Poor suppressed trees with little to no potential for future growth will not be protected and may be slashed if needed post-harvest. Harvesting should promote the rejuvenation of some quaking aspen within the stand where it is currently present and is being suppressed from coniferous competition. Ample natural regeneration of lodgepole pine and Douglas-fir is expected within the salvaged units. Approximately 5-15 tons of coarse woody debris would be left within the units.

Overstory Removal: This prescription is designed to remove most of the overstory Douglas-fir and leave most of the overstory ponderosa pine down to approximately 2-6 TPA on average in order to allow the established regeneration more growing space and create more growing space for additional regeneration. It will also reduce competition with ponderosa pine trees that are planned to be planted in understocked portions of the unit where regeneration did not become established following the last harvesting. The overstory ponderosa pine trees will be left as a future seed source, for structural diversity, and as future snags and snag recruits within the stand. Those trees that have basal scarring, have poorer crowns, are in areas that are more heavily regenerated, or those Douglas-fir that are infected with root rot will be targeted for removal. A majority of the slash will be left for coarse woody debris and nutrient recycling.

\section{Cumulative Effects}

The risk of negative cumulative effects occurring is very low since many of the proposed treatments are designed to emulate historic processes and bring the stands back toward more historic stand conditions. Future possible harvesting on private lands within the analysis area would tend to make age classes younger, but would not be expected to cause large negative effects to forest structure and cover types since they would be expected to be relatively small in extent. Some blowdown could occur on private ownership bordering cutting units due to proposed harvesting. The likelihood of this happening would be low, and would be expected to be small in extent due to the fact that most of these bordering lands have already been harvested in the past several decades. 


\title{
Forest Health
}

\begin{abstract}
Alternative A
Under this alternative, stand health would continue to decline as stands age and competition becomes more intense. Diseases including root rot and mistletoe would continue to increase and reduce overall stand health and growth. The epidemic of bark beetles is likely to continue to expand and kill most of the remaining green lodgepole pine that are currently not hit within the stands that are proposed for salvage and the epidemic is likely to spread beyond those into the numerous other stands within the section that contain lodgepole causing more loss of value and growth. Additionally, there would be a high risk that the epidemic would spread to adjacent ownerships and affect those owners and their forested stands as well.
\end{abstract}

\section{Alternative B}

The silvicultural prescriptions found on the preceding page describe the proposed treatments in detail.

The salvage harvesting on approximately 170 acres would reduce beetle populations in the area by direct removal of infected trees and by reducing potential food sources and stand densities. While there is still an abundance of lodgepole pine stands in the area that are at high risk to bark beetles, the proposed harvesting would have a high likelihood of bringing this epidemic back to endemic levels, in which case many of the adjacent stands may not be severely affected by the current epidemic.

Salvage harvesting would not take place until the summer of 2006 after the next flight of bark beetles occur. So it is anticipated that this epidemic will spread both within the identified harvest units as well as expand outward in some locations before any harvesting takes place. In some locations the harvest units were laid out approximately 50-100 feet out from infested trees to account for this spread, however it is also anticipated that some new pockets of beetle hit trees will be found outside the current proposed units as well as expansion of the existing units. It is likely that these newly hit areas will be relatively small in scale, however the potential for a large expansion does exist. On a relatively small scale, harvest units would be expanded and some new small units would be created that are in addition to those found on the proposed harvest maps found in this EA to capture this new mortality, and eliminate these new epicenters that occur. These modifications would take place as part of this analysis up to October $15^{\text {th }}$ of 2009. Should wide spread expansion occur that are outside the effects analysis in the EA, more analysis would be needed.

Proposed salvage operations would also improve forest health by removing mistletoed trees and other trees that are in very poor health. This in turn would create growing space for the establishment of a younger, thriftier stand of regeneration as well as for the residual trees. Overall stand health would be improved which would make the stands much less susceptible to insect and disease outbreaks.

Harvesting in areas where root rot is present would be likely to increase the spread and intensity of this disease in the remaining trees, however prescriptions are designed to leave healthier trees that are more resilient to attack and promote less susceptible species such as ponderosa and lodgepole pine. As a result of this, the effects to the spread of tree diseases as a result of the proposed activities is expected to be very low. Mortality that occurs due to the possible increase in root rot may be salvaged as part of this project.

Harvesting of the 38 acre overstory removal would remove overstory trees to create growing space for the regeneration that is established and for trees would be planted as part of this proposal. Trees that 
are in poorer health, are infected with root rot, and/or have basal scarring would be selected for removal and those trees that are in the best health on average would be left.

With proposed treatments blowdown of some residual trees could be expected. This could have a negative effect to forest health by providing a food source for bark beetles. However, these trees are likely to be salvaged if this should occur, which would virtually eliminate this risk.

\section{Cumulative Effects}

No negative cumulative effects are expected to occur to forest health as a result of this project. The proposed treatments would reduce insects and disease populations in the area directly and would greatly improve forest health and vigor. Cumulatively this would serve to reduce the risk of insect and disease outbreaks in the area and minimize the risk of populations building on state ownership that could affect adjacent landowners in the near future.

\section{Fire Hazard}

\section{Alternative A}

Fire hazard and the risk of stand replacing fires on the project area would not be affected as a result of this alternative. The stands would remain at high fuel loadings and ladder fuels would continue to increase at levels well above those expected without the exclusion of fire. Stand densities and down fuel loadings would be expected to increase over time as would the amount and severity of insects and disease mortality. This condition would be expected to increase over time until the fuels are modified by an ecological disturbance or by management activities.

\section{Alternative B}

The reduction in stand densities and removal of forest products and forest fuels proposed in this alternative on 208 acres would greatly reduce the risk of moderate intensity to stand replacing fires. If fires were to burn through the area, they would be more likely to be light to moderate severity as a result of this reduction in fuels except in extreme fire conditions. With the reduction in fuels and thinning of the tree canopies, fire would be more likely to be ground fires that would burn in the understories and be more controllable than stand replacing crown fires. Treatments would reduce ladder fuels by removing trees, which would reduce the chance of fire reaching and carrying in to the overstory. Eventually over time as the stands regenerate and become older with larger trees, more fuels, and tighter canopies, the risk of higher intensity fires would again begin to increase.

Some of the tops, limbs, and unusable pieces of trees would be left in the forest to recycle nutrients and to provide coarse woody debris for microorganisms, small mammals, and forest health. This slash would increase fire hazard in the ground fuels on the site for up to approximately 3-5 years as it cures and decomposes. Slash left in the woods would meet the State Hazard Reduction Laws. There would be slash piles at the landings, which would be burned or otherwise disposed of within approximately 2 years of their creation. The effects of this short-term increase in ground fuels would be somewhat offset by the reduction in the overall volume of fuels.

\section{Cumulative Effects}

For the first three to five years fire hazard would not likely be reduced due to the offsetting effects of decreased stand densities but increased slash loadings. In the long-term however, the decreased risk of high intensity and stand replacing fires on 208 acres would provide a net benefit within the analysis area. Should a fire start in the overstocked or heavily diseased stands and build to high intensities, it 
puts most of the nearby stands at increased risk regardless of their fuel loads or stocking levels due to the fire intensity that was allowed to build. By removing 208 acres from this heavily stocked and diseased state, the surrounding landscape would benefit through reduced risk of higher intensity fires and through creation of areas where fire might be more controllable.

\section{Old Growth}

\section{Alternative A}

The amount of old growth on the project area would remain the same as would the amount of old trees within the other stands in the project area. Stands would continue to age and over time some additional areas might meet the definition of old growth provided some disturbance did not change their age, size, or stocking characteristics. Those stand that would not be harvested might eventually grow old and large enough to qualify as old growth.

\section{Alternative B}

The amount of old growth on the project area would remain the same since no stands that meet the definition of old growth are proposed for harvest.

Old trees as well as mature trees within the proposed harvest areas would be cut. This could result in fewer stands being eligible to be recruited into the old growth classification in the near-term, which would be a negative effect to old growth of the proposed project. Harvesting would not preclude stands from becoming old growth in the future since all size and age classes would be represented post-harvest, however stand characteristics would be changed and would delay their recruitment into old growth classification. Harvesting would allow residual trees to grow larger and faster which could enhance attaining old growth status in the future.

\section{Cumulative Effects}

The proposed project would not decrease the amount of old growth currently in the analysis area, however it could delay the amount of old growth stands available for recruitment into old growth status in the near-term, which would result in a negative short-term effect to old growth amounts and abundance in the area.

\section{Noxious Weeds}

\section{Alternative A}

It is expected that noxious weed infestations would increase over time. Heavy tree canopies would continue to compete with weeds, but they would continue to spread across the analysis area. Biological control agents might help decrease the densities of infestations of knapweed in localized areas as they become more established.

\section{Alternative B}

The proposed activities would result in an increase in ground disturbance. Mechanized equipment and ground disturbance could increase or introduce noxious weeds throughout roads and forested areas. Seeds of weeds such as thistle and knapweed are likely to be scattered throughout the forested areas and the reduction of canopy and resulting disturbance from the timber harvest activities is expected to provide the catalyst for spread. 
For this project an Integrated Weed Management (IWM) approach would be implemented that would include: prevention, revegetation and weed control measures for spot outbreaks, which are considered the most effective weed management treatments. Short-term goals would be to reduce existing noxious weed populations and increase native plants and seeded grasses. Where weeds are replaced with grasses, erosion would be reduced due to the improved plant cover. Localized herbicide applications would be used, primarily along disturbed roadside edges and spot treatments of small infestations. An herbicide treatment of most of the noxious weeds along the roadsides would occur prior to proposed activities and following completion of activities.

To protect water quality, herbicide would not be applied where runoff could enter surface waters or riparian features. Existing biological control efforts for knapweed would be monitored and supplemented if necessary.

In order to minimize the spread of noxious weeds all off-road equipment would be cleaned and inspected prior to entry to harvest areas and the overstory removal unit where knapweed is present and one of the salvage units where knapweed is nearby would be prioritized to be harvested last so that weeds are not carried on equipment to relatively weed free units.

\section{Cumulative Effects}

With the planned IWM approach, cumulative effects of the spread and establishment of noxious weeds in the area as a result of the proposed activities are expected to be minimal although populations are expected to continue to increase over time. 


\section{Attachment C Wildlife}




\title{
Wildlife
}

\section{Threatened and Endangered Species Existing Conditions}

\author{
Grizzly Bear (Federally threatened)
}

Grizzly bears are the largest terrestrial predators in North America, feasting upon deer, rodents, fish, roots and berries, as well as a wide assortment of vegetation (Hewitt and Robbins 1996). Depending upon climate, abundance of food, and cover distribution, home ranges for male grizzly bears in northwest Montana can range from $60-500 \mathrm{mi}^{2}$ (Waller and Mace 1997). The search for food drives grizzly bear movement, with bears moving from low elevations in spring to higher elevations in fall, as fruits ripen throughout the year. However, in their pursuit of food, grizzly bears can be negatively impacted through open roads (Kasworm and Manley 1990). Such impacts are manifested through habitat avoidance, poaching, and vehicle collisions.

The southern edge of the project area is also the southern edge of the Northern Continental Divide Ecosystem grizzly bear recovery area. With vernal and permanent pools within and adjacent to the project area, the immediate area surrounding the project area is known to have frequent grizzly bear activity (J. Jonkel, MT FWP, personal communication, February 2006). Thus, the proposed project area may be part of one or more grizzly bear home ranges. The cumulative effects analysis area for grizzly bears will be the Monture Landers Fork Bear Management Unit (BMU) of the NCDE, and encompass approximately 76,676 acres (approximately 120 square miles).

Grizzly bears are known to be more vulnerable to human interaction in areas with high open road densities or ineffective road closures. Currently there are 1.25 miles of open road per square mile (simple linear calculation; 150 miles of open road), and 1.69 total miles of road per square mile (203 miles of road), within the 120 square mile analysis area. Within the project area, there are approximately 4.85 miles of road, all of which are currently open to motorized vehicles. This results in an open road density of approximately 4.85 miles of open road per square mile (project area is approximately 1 square mile or 640 acres) within the project area.

\section{Gray Wolf (Federally endangered)}

Wolves north of Interstate 90 were recently re-classified as endangered under the Endangered Species Act. Cover, and road and prey densities likely have some influence on wolves. For cumulative effects analysis, the analysis area will be the same as that of the grizzly bear. Wolf activity near the analysis area is currently unknown. A road-killed wolf was recently located east of the project area along Highway 200, and additional wolves have been periodically observed nearby (http://westerngraywolf.fws.gov/wk11182005.htm). Additionally, two sets of potential wolf tracks were observed within the project area on a recent field visit (M. McGrath, SWLO Wildlife Biologist, personal observation, 9 February 2006). White-tailed deer, elk, and moose are known to winter in the area (Bob Henderson, MT FWP, personal communication, January 2006). Parcels adjacent to the project area on the north, east, and west are currently managed by the Sieben Ranch, where domestic sheep are regularly grazed. Currently, no known wolf den or rendezvous site is located within 1 mile of the project area.

Canada Lynx (Federally threatened) 
Lynx are currently classified as threatened in Montana under the Endangered Species Act. In North America, lynx distribution and abundance is strongly correlated with snowshoe hares, their primary prey. Consequently, lynx foraging habitat follows the predominant snowshoe hare habitat, early- to mid-successional lodgepole pine, subalpine fir, and Engelmann spruce forest. For denning sites, the primary component appears to be large woody debris, in the form of either down logs or root wads (Squires and Laurion 2000, Mowat et al. 2000, Koehler 1990). These den sites may be located in regenerating stands that are $>20$ years post-disturbance, or in mature conifer stands (Ruediger et al. 2000, Koehler 1990).

Elevations in the project area range from 5,080 to 5,620 feet, and suitable habitat types (Pfister et al. 1977) for potential foraging occur in the area. Snowshoe hares are important lynx prey and are associated with dense young lodgepole pine stands, as well as mature stands with subalpine fir understories. Within the project area, there are approximately 220 acres of mature foraging habitat, and approximately 91 acres of temporary non-habitat. Within the 24,720 acre cumulative effects analysis area, 15,278 ac are managed by the U.S. Forest Service, 7,007 ac are privately owned, 1,987 ac are managed by DNRC, and 922 ac are managed by The Nature Conservancy. Of this area, approximately 6,648 acres burned in the 2003 Snow Talon fire. Lynx likely utilize the area year round.

\section{Sensitive Species Existing Conditions}

Fisher

The fisher is a medium-sized animal belonging to the weasel family. Fishers prefer dense, lowland spruce-fir forests with high canopy closure, and avoid forests with little overhead cover and open areas (Powell 1978, Powell 1977, Kelly 1977, Clem 1977, Coulter 1966). For resting and denning, fishers typically use hollow trees, logs and stumps, brush piles, and holes in the ground (Coulter 1966, Powell 1977). Because fishers prefer stands with dense canopy cover, areas that have experienced high intensity fires would not be suitable fisher habitat for several decades. However, newly created snags would provide needed coarse woody debris over time.

Within the project area, there are approximately 546 acres of habitat types (i.e., Pfister et al. 1977) that fisher prefer to use. Because these habitat types are present does not necessarily indicate that these acres are currently suitable for use by fisher (i.e., stand structure, canopy closure, etc.). Adjoining lands within a 1-mile radius, north of Highway 200, include: (1) lands managed by the Sieben Ranch, on which timber has been intensively managed over the past 40 years; (2) lands owned by The Nature Conservancy, but had previously been managed for timber in an industrial setting; (3) lands managed by DNRC; and (4) land managed by the U.S. Forest Service. Thus, while preferred fisher habitat types may currently exist within the project and analysis areas, suitable habitat may not.

\section{Pileated Woodpecker}

The pileated woodpecker is one of the largest woodpeckers in North America (15-19 inches in length), feeding primarily on carpenter ants (Camponotus spp.) and woodboring beetle larvae (Bull and Jackson 1995). The pileated woodpecker nests and roosts in larger diameter snags, typically in mature to old-growth forest stands (Bull et al. 1992) (McClelland et al. 1979). Due primarily to its large size, pileated woodpeckers require nest snags averaging 29 inches diameter at breast height (dbh), but have been known to nest in snags as small as 15 inches dbh in Montana (McClelland 1979). Pairs of 
pileated woodpeckers excavate 2-3 snags for potential nesting sites each year (Bull and Jackson 1995). Snags used for roosting are slightly smaller, averaging 27 inches dbh (Bull et al. 1992). Overall, McClelland (1979) found pileated woodpeckers to nest and roost primarily in western larch, ponderosa pine, and black cottonwood. The primary prey of pileated woodpeckers, carpenter ants, tend to prefer western larch logs with a large end diameter greater than 20 inches (Torgersen and Bull 1995). Thus, pileated woodpeckers generally prefer western larch and ponderosa pine snags $>15$ inches dbh for nesting and roosting, and would likely feed on downed larch logs with a large end diameter greater than 20 inches.

The most abundant habitat types (Pfister et al. 1977) within the affected area are the Douglas-fir/dwarf huckleberry, and subalpine fir/dwarf huckleberry (Stand Level Inventory database). Within the project area, there are approximately 398 acres that are predominately Douglas-fir/lodgepole pine, with average stand diameter $\geq 15$ inches dbh that may be considered suitable pileated woodpecker habitat (SLI database). The cumulative effects analysis area will encompass the project area and a 1-mile radius surrounding the affected School Trust parcel.

\section{Black-backed Woodpecker}

The black-backed woodpecker is an irruptive species that forages opportunistically on outbreaks of wood boring beetles primarily in recently burned habitats, and to a lesser degree in unburned habitats. It is also considered to be a sensitive species in Montana. Although the black-backed woodpecker's nesting and foraging requirements are thought to be tightly linked with burned areas, it does nest and forage in unburned forest in response to insect outbreaks (Hutto 1995, Bull et al. 1986). Burned forests tend to be used immediately after burns occur (approximately 1 - 5 years). Large, densely stocked non-salvaged stands with an abundance of trees greater than or equal to 12 inches dbh appear to provide the greatest benefit to black-backed woodpeckers for foraging and nesting. Black-backed woodpeckers are also found in green forests with high levels of insect activity.

The extensive and intensive wildfires of western Montana in 2003 created large amounts of potentially suitable habitat that will be available for black-backed woodpeckers at the landscape scale. Because of the close relationship of black-backed woodpeckers and wildfire, the analysis area was defined as an area inclusive of two major fires near the project area: the Snow-Talon and Moose-Wasson fires, located approximately 3 miles to the north, and 11.5 miles to the southwest of the project area, respectively. Within the 1,800 acre Moose-Wasson fire, a total of 590 acres burned: approximately 294 acres of low severity burn, 296 acres of moderate severity, and zero acres of high severity burn. Because the MooseWasson fire burned as a mosaic, there were many acres within the perimeter of the fire that did not burn. Thus, few acres of black-backed woodpecker habitat were created during the Moose-Wasson fire. Within the 37,700-acre Snow-Talon fire is located approximately 3 miles north of the project area, 32,370 acres burned, including approximately 4,504 acres within the Scapegoat Wilderness Area. This fire also experienced 26,500 acres of high, 1,690 acres of moderate, and 4,180 acres of low burn severity, creating approximately 16,697 acres of potential black-backed woodpecker habitat (i.e., high burn severity in stands $>80$ years old; Scott Schrenk, Helena National Forest biologist, personal communication, March 2004). The USFS may salvage up to 2,700 acres of moderate and high severity burn within the Snow-Talon fire, but outside of designated roadless and wilderness areas, and $80 \%$ to 95\% of the available high-quality black-backed woodpecker habitat would remain untreated (Scott Schrenk, USFS, personal communication, March 2004). Thus, potential salvage operations by the USFS on the Snow-Talon Fire would still leave several thousand acres of potential black-backed woodpecker habitat post-harvest. 


\section{Big Game - Deer, Elk, and Moose}

Big game generally avoids open roads, but becomes more tolerant of closed roads in the area over time (Lyon 1998). Densely stocked thickets of conifer regeneration and overstocked mature stands provide thermal protection and hiding cover for big game in winter, which can reduce energy expenditures and stress associated with cold temperatures, wind, and human-caused disturbance. Additionally, extensive (e.g., $\geq 250$ acres) areas of forest cover $\geq 0.5$ miles from open roads serve as security for elk. Thus, removing cover that is important for wintering big game through forest management activities can increase their energy expenditures and stress in winter. Reductions in cover could ultimately result in a reduction in winter range carrying capacity and subsequent increases in winter mortality within local big game populations.

Within the project area, there are approximately 4.85 total miles of road per square mile, all of which are currently open to motorized vehicles. There are approximately 466 acres of forest cover that could be used for snow-intercept cover. There currently is no forest cover within the project area that could be used for security cover during the hunting season due to the abundance of open roads within the project area.

The cumulative effects analysis area encompasses both the Alice Creek and Red Mountain grizzly bear BMU subunits, which is approximately 230 square miles (146,851 acres). There are approximately 76,490 acres of forest cover that could be used for snow-intercept cover, although only approximately 26,843 acres are near big game winter range. Approximately 58,537 acres (40\% of cumulative effects analysis area) of forest cover within the analysis area could be used for security cover during the hunting season. Winter range largely occurs on the southern and eastern boundaries of the analysis area.

\section{Biological Diversity}

The project area currently has potential for a relatively high index of biological diversity (e.g., species richness) due to the diversity of habitats and forest age classes that are present: approximately 7.7 acres in 3 wetland potholes; 27 acres in grassland; 143 acres in forest $<40$ years old; 111 acres of forest $\geq 40$ yrs and $<100$ years old; and 357 acres of forest aged $\geq 100$ yrs. Many of these forest age classes are dispersed relatively evenly throughout the parcel, with approximately 36,251 ft of hardedge perimeter. Such perimeter allows for edge effects and the dispersion of edge-related wildlife species (e.g., cowbirds, raccoons, etc.) throughout the parcel. As a result, there would likely be a higher diversity of wildlife species present within the project area, than if the project area was a contiguous, single-aged forest stand.

At a broader scale (approximately 117 square miles centered on the project area), the project area is part of a biologically diverse community. This analysis area includes portions of the Keep Cool Hills and the town of Lincoln, the Blackfoot and Landers Fork Rivers, the large grasslands between Poorman and Humbug Creeks, and between Stonewall and Keep Cool Creeks. The forested areas incorporate public and private holdings that have had diverse land management over the last 150 years. As a result, the forested areas include very young through old age classes. Thus, this landscape incorporates riparian, grassland, and forested ecosystems, their associated ecotones, and an urban/wild interface. This would result in a biologically diverse landscape for a variety of terrestrial wildlife species. 


\section{Connectivity and Fragmentation}

Philosophically, connectivity and fragmentation are relative to the organism, its life history characteristics, and the scale at which it operates. As an example, the forest-dwelling fisher will have much different connectivity and fragmentation issues than the short grass prairie's mountain plover. This analysis will examine connectivity and fragmentation for forest dwelling wildlife that are associated with either young or older forest to evaluate effects from differing perspectives.

As described under Biological Diversity, the project area consists of a variety of forest age classes, with the largest being approximately 357 acres of relatively contiguous forest aged $\geq 100$ years, with approximately 143 acres of forest $<40$ years dispersed in 5 blocks in the NW, SW, and SE corners of the parcel. From the perspective of wildlife associated with early successional forest and with a home range $\leq 1$ square mile, the project area currently has low connectivity among patches and would be considered moderately to highly fragmented. From the perspective of wildlife associated with older forest habitats and has a home range $\leq 1$ square mile (e.g., pileated woodpecker), the project area currently has moderate to high connectivity among patches and would be considered to have low to moderate fragmentation.

For the broader scale analysis, we will analyze the same approximately 117 square mile analysis area covered under Biological Diversity. For an early successional/open habitats species like the kestrel, there currently are the grassland habitats along the valley bottom and towards the southwestern portions of the analysis area. For early successional forest, old clearcuts are interspersed throughout the landscape on a variety of ownerships (e.g., The Nature Conservancy, DNRC, USFS). However, the majority of the contiguous early forest habitat occurs within the northeastern quarter of the analysis area on the Sieben Ranch. The grasslands of the southwestern portion of the analysis area are connected to the early successional lands of the northeast quarter by grasslands and riparian zones that run along Highway 200. Thus, the analysis area has two large early successional/grassland fragments that are naturally connected by topographic and vegetative features.

For wildlife associated with older, mature forest (e.g., lynx), the habitat runs on a northwest to southeast corridor from the Keep Cool Hills into the hills around Seven-Up Pete Creek and Crater Mountain. The older forest, however, runs along an elevational gradient, with larger blocks of older forest at higher elevations, and fragmented older forest interspersed among a matrix of more open early successional forest at the lower elevations. Mining claims, recreational corridors (i.e., Landers Fork River), cabin sites, and formerly industrial forests have had the most impact in fragmenting the older forests at these lower elevations. Thus, a lynx, for example, would need to travel through the lower elevation matrix of younger forest and cross the Blackfoot River in order to travel from one large, contiguous mature forest patch to another along the northwest-southeast corridor. As a result of the past actions by various landowners, including DNRC, the mature forest corridor has been moderately fragmented at the lower elevations, and heavily fragmented in the northeast quarter of the analysis area.

\section{Environmental Consequences - Predicted Effects on Relevant Resources of All Alternatives}




\title{
Threatened and Endangered Species
}

\author{
Grizzly Bear (Federally threatened)
}

\section{Alternative A}

Under the No Action alternative, timber would not be harvested, existing roads would not be closed, and the existing mountain pine beetle infestation would likely expand. As a result of the mountain pine beetle infestation, the beetles would continue to infest lodgepole pine, and some ponderosa pine, that would likely die within a few $(<5)$ years. The dead lodgepole would likely stand for 5 to 10 years after death, and continue to provide some hiding cover for grizzly bears. However, after 5 to 10 years of when the lodgepole dies, it will likely fall, and may provide some cover for bears, providing that the fallen lodgepole accumulates to some height or jackstraws in places. Currently, within the affected stands, approximately 55\% of the trees are lodgepole pine, and $40 \%$ Douglas-fir, and approximately 154 acres are infested with mountain pine beetle. Should the mountain pine beetle spread throughout the remainder of the project area, or beyond, there would likely be a loss of cover near the open roads within the project area that may jeopardize grizzly bears. Additionally, the project area, along with habitat on adjoining private lands, includes numerous wetland potholes that attract grizzly bears in spring. Thus, loss of hiding cover near open roads, in the vicinity of natural topographic features known to attract grizzly bears may lead to direct and indirect effects to grizzly bears. With domestic sheep grazing on adjacent private lands, and a history of management removals of grizzly bears due to sheep depredations, there may also be low to moderate risk of cumulative effects to grizzly bears as a result of the No Action alternative.

\section{$\underline{\text { Alternative B }}$}

The proposed action would harvest a total of approximately 208 acres (170 acres of salvage harvest and 38 acres of overstory removal), construct approximately 0.5 mile of new road, and close approximately 1 mile of road ( 0.5 mile new road and 0.5 mile of existing road). The proposed action would occur in two operating periods over 3 consecutive years, with the first operating period occurring between June 15 and October 15, to reduce the likelihood of potential conflict with Spring use of the area by grizzly bears. The timing of the second operating period would be decided at a later date and would be designed to have the least impact to numerous resources, including grizzly bears, while also minimizing potential future timber loss to insects. Additionally, several potential salvage harvest units were designed to retain vegetative screening next to open roads, and upon completion of the project, new roads would be gated and posted with signs closing the roads to motorized access. An approximately 0.3 mile segment of existing road upslope of the overstory removal unit would be closed with earth berms and be allowed to revegetate. Finally, where topography and other vegetation does not currently provide for grizzly bear hiding cover along the project area's northeast property line, a 33 foot wide vegetative screen would be retained to provide for hiding cover or screening from an open road.

Because the primary purpose of the proposed action is to salvage timber infested with mountain pine beetles, the options available for mitigation and unit design are somewhat predicated upon existing species distribution and infestation, in addition to topography adjacent to roads. The proposed action, as described in the preceding paragraph, was designed to minimize grizzly bear vulnerability from motorized access along open roads. While the proposed harvest would remove approximately $60 \%$ of the standing tree volume within the proposed harvest units, much of the Douglas-fir would be retained, and would be distributed throughout the harvest units, providing some limited cover for grizzly bears. Hiding cover would be retained along open roads and property lines, to the extent possible as 
determined by existing vegetation and beetle infestation. Thus, the proposed action would help minimize future grizzly bear vulnerability through reducing the level of mountain pine beetles in the area, while retaining hiding cover along open roads. However, the project area and its immediate vicinity has several potholes that are known to attract a variety of wildlife, including grizzly bears. Additionally, the area is experiencing increasing ATV use by the public. Most ATV users do stick to the established roads, although new, illegal trails have been established in the NW corner of the project area. With local habitat features attracting grizzly bears, and increasing ATV use, the proposed new road construction and timber harvest would likely allow ATV users access to habitat in which grizzly bears are currently secure from disturbance. Thus, there is the potential for low to moderate risk of direct and indirect effects to grizzly bears as a result of the proposed action.

The project area is part of a larger landscape that receives heavy recreational use by the public, with adjoining privately-owned parcels permitting public recreation. In 2003, 30\% of the analysis area was radically changed through the Snow Talon Fire, which burned 32,370 acres, 26,500 of which in stand replacement fire. Portions of the Scapegoat Wilderness area also comprise portions of the analysis area. The remaining lands are composed of a mixture of School Trust lands, The Nature Conservancy, USFS, and private lands, all of which are subject to land management. Large portions of these lands have been subject to both recent and historic timber harvest, as well as livestock grazing, including a significant sheep herd on private and DNRC lands. Historically, grizzly bears have had trouble with the sheep, and have either been re-located or destroyed.

Within the analysis area, given the recent vegetative changes from the Snow Talon fire, the proposed new road construction and timber harvest, as well as past harvests and domestic livestock grazing, one of the most important threats to grizzly bears is open road densities and visual screening cover along those roads. The proposed action attempts to account for these threats to bears through closing all new road construction and an additional 0.5 mile of road, while also providing visual screening cover between open roads and proposed harvest units within the project area. After careful evaluation, effective closure of additional roads would not be possible due to the gentle terrain and numerous access points from adjoining properties. Additionally, reducing hiding cover in the northeast corner of the project area, an area with several potholes, may increase grizzly bear vulnerability. As a result, there may be low to moderate risk of cumulative effects to grizzly bears as a result of the proposed action.

Gray Wolf (Federally endangered)

\begin{abstract}
Alternative A
Currently, the status of wolves in the area east of Lincoln is unknown. Although wolves have been seen in the vicinity recently. As discussed under the No Action Alternative for grizzly bears, should the mountain pine beetle infestation spread throughout the remainder of the project are, or beyond, there would likely be a loss of cover near open roads that may jeopardize wolves. With domestic sheep grazing occurring on adjacent private lands, further reductions in the endangered wolf population may result from possible future livestock depredations. Thus, loss of hiding cover near open roads may lead to direct and indirect effects to wolves. With domestic sheep grazing on adjacent private lands, and a history of management removals of grizzly bears due to sheep depredations, there may also be minimal to moderate risk (depending on the level of wolf activity in the area, once it is determined) of cumulative effects to wolves as a result of the No Action alternative.
\end{abstract}




\section{$\underline{\text { Alternative B }}$}

Similar to the effects for grizzly bears, the proposed action has been developed with mitigations that should help minimize impacts to wolves. Namely, (1) amoeboid units to break up sight distance; (2) retention of vegetative screening next to open roads, where possible; and (3) closing the proposed new road construction and an additional 0.5 mile of currently open road. Should wolves establish a den or rendezvous site nearby, mitigations pursuant to ARM 36.11.430 would be implemented.

Reduction in cover would likely benefit wolves because it would likely make deer, elk, and moose more vulnerable to predation, and would lend itself to a wolf pack's manner of hunting. However, the presence of domestic sheep in the surrounding landscape may lead to removals of wolves from the population due to livestock depredations. With these factors in mind, there would likely be low risk of direct or indirect effects, and low to moderate risk of cumulative effects to wolves as a result of the proposed action, provided that wolves have become established in the area.

\section{Canada Lynx (Federally threatened)}

\section{Alternative A}

Under the No Action alternative, the mountain pine beetle infestation may spread, reducing cover, and creating lodgepole pine snags. As a result, over time, the lodgepole pine would likely regenerate in dense stands and the legacy snags would eventually fall, creating young foraging habitat, and possibly denning habitat for lynx. However, there would likely be corresponding losses in mature foraging habitat, which is important for lynx winter survival (J. Squires, USDA Forest Service, personal communication, February 2005). At the scale of the LAU, losses of mature foraging habitat to mountain pine beetles would add to the losses due to the Snow Talon fire of 2003, and reductions in mature foraging habitat on private lands. Habitat affected by mountain pine beetles within the project area and by the Snow Talon fire would be classified as temporary non-habitat, and would thus, be unsuitable, until sufficient forest regeneration occurred to provide young foraging habitat. Thus, the No Action alternative would likely have low to moderate risk of temporary (10 - 15 years) direct, indirect, and cumulative effects to lynx.

\section{Alternative B}

The proposed action would harvest timber on approximately 146 acres of the 220 acres of mature foraging lynx habitat during the first operating period. As a result, lodgepole pine trees that, under the No Action Alternative, would normally become snags as a result of infestation by mountain pine beetles, would be removed and would not be permitted to fall and possibly create future lynx denning habitat. However, the forest would still likely regenerate densely with lodgepole pine post-harvest, and possibly create young foraging habitat. The second operating period, should it be necessary, would remove additional trees that would be infested with mountain pine beetles at that time. It would not remove trees that have fallen as a result of a blow down event that would affect greater than 5 acres without further documentation or analysis. The proposed action would likely have low risk of temporary (10 - 15 years) direct and indirect effects to lynx.

Within the cumulative effects analysis area, lynx would be affected by many sources of disturbance: the proposed action, heavy winter recreation use involving snowmobiles, the Snow Talon Fire of 2003, and past and future timber harvest on private lands. Prior timber harvest on private lands adjoining the project area have created a mosaic of grassland and brushy thicket, which, although not ideal habitat, may provide for snowshoe hares, the lynx's primary prey. As the private lands and lands burned by the Snow Talon fire gradually become reforested with seedlings and saplings, the value of these lands 
for early lynx foraging habitat will increase. However, until seedlings and saplings become established in the burned area, lynx may look elsewhere for food, because approximately $27 \%$ of the analysis area burned. The area surrounding Lincoln, MT is a popular winter destination for snowmobile enthusiasts from Helena, Great Falls, and Missoula. As such, the extensive snowmobile trails created by these enthusiasts provide pathways for competing carnivores (e.g., wolves, coyotes, and mountain lions) to gain access to prey within the lynx's winter habitat. The proposed action would further reduce the amount of mature foraging habitat available within the LAU by approximately 146 acres, and cause those same acres to be temporary non-lynx habitat for approximately 20 years. However, the central approximately 6,400 acres of the LAU are largely a single, large block of mature foraging habitat, and likely receives extensive use by lynx. Thus, there would likely be low risk of cumulative effects to lynx as a result of the proposed action because of the presence and abundance of mature foraging habitat in the LAU.

\section{Sensitive Species}

Fisher

\section{Alternative A}

Under the No Action alternative, the mountain pine beetle infestation may spread, reducing cover, and creating lodgepole pine snags. As a result, over time, the lodgepole pine would likely regenerate in dense stands and the legacy snags would eventually fall, leaving legacy coarse woody debris for the future forest that would develop around it. Because fisher have been linked to mature forest, the No Action alternative would allow potentially suitable fisher habitat to be removed from the landscape. However, the legacy snags and coarse woody debris that would result from the alternative would provide for habitat features characteristic of fisher habitat, once the forest has regenerated and progressed to become mature forest once again. Given the forests within a 1 mile radius of the project area are largely in the early successional stages, the surrounding landscape is not currently conducive to fisher foraging or movement. Thus, the No Action alternative would likely have low risk of direct, indirect effects to fisher because of habitat conditions in the surrounding landscape, and there would likely be low to moderate risk of cumulative effects to fisher because of the loss of potentially suitable habitat, and the lack of suitable habitat in the surrounding landscape.

\section{Alternative B}

The proposed action would salvage harvest approximately 150 acres of the approximately 546 acres of habitat types fisher prefer to use within the project area. The results of this process would retain an average of one large snag and one snag recruit per acre, with likely little larger diameter material remaining for larger diameter coarse woody debris. This would differ from the No Action alternative because there would be many fewer legacy snags and coarse woody debris that would be considered fisher habitat features under future mature forest. However, given the current lack of suitable fisher habitat within the mile radius surrounding the project area, it would likely be at least 60 years before the surrounding landscape would be suitable for fisher, providing adjacent land owners permit the forest to attain those conditions. Thus, there would likely be low risk of direct and indirect effects to fisher, due to the lack of suitable fisher habitat surrounding the affected parcel, and likely low to moderate risk of cumulative effects to fisher from the proposed action for similar reasons.

Pileated Woodpecker

\section{$\underline{\text { Alternative A }}$}


Under the No Action alternative, the beetle infestation would continue to spread, creating additional snags and future coarse woody debris while simultaneously reducing canopy closure. While the No Action alternative may create an abundance of snags and future coarse woody debris on which pileated woodpeckers could feed, the alternative also increases the risk of losing potential nesting habitat due to the likely reduction in canopy closure. Thus, there would be low to moderate risk of direct and indirect effects to pileated woodpeckers as a result of the No Action alternative.

Through the No Action alternative, the beetle infestation would likely grow to affect forested stands on nearby USFS land within the analysis area. Similar to the discussion regarding direct and indirect effects, there would be an increased availability of snags and coarse woody debris within the analysis area, however, there would be corresponding decreases in canopy closure that may negatively effect nesting habitat suitability for pileated woodpeckers. Additionally, with the abundance of young forest conditions on adjoining private lands, the No Action alternative would likely further reduce the amount of potentially suitable pileated woodpecker habitat within the analysis area. Thus, there would be a low to moderate risk of cumulative effects to pileated woodpeckers as a result of the No Action alternative.

\section{Alternative B}

The proposed action would salvage timber from approximately 147 acres of the approximately 398 acres of pileated woodpecker habitat within the project area. As such, the proposed action would reduce: (1) canopy closure; (2) snag availability to an average of 1 snag and 1 snag recruit per acre among the affected acres; (3) the likelihood of accumulating larger diameter (e.g., >10 inches dbh) coarse woody debris; and (4) the habitat suitability of the affected acres for pileated woodpeckers. However, it would also reduce the likelihood that the mountain pine beetle infestation would spread and affect additional acres of pileated woodpecker habitat. Given these factors, there would likely be low risk of direct and indirect effects to pileated woodpeckers as a result of the proposed action alternative.

Within the context of the cumulative effects analysis area, given the abundance of young forest conditions on adjoining private lands, the proposed action would likely further reduce the amount of potentially suitable habitat within the analysis area. Although, the proposed action would likely contain the beetle infestation to the currently affected acreage. Thus, there would likely be low to moderate risk of cumulative effects to pileated woodpeckers as a result of the proposed action.

\section{Black-backed Woodpecker}

\section{Alternative A}

Under the No Action alternative, the mountain pine beetle infestation would likely expand, and possibly attract a few pairs of black-backed woodpeckers for nesting and foraging. However, for the next 3 to 4 years, black-backed woodpeckers would largely, be located within and around the nearby Snow Talon and Moose-Wasson Fires because that area is a large contiguous block of higher quality habitat for this species. These recent fires would be a source of wood boring beetles, their primary food source, as well as nest sites. Within the Snow Talon fire, the USFS estimates that there is approximately 16,700 acres of potential black-backed woodpecker habitat. Given the planned salvage on USFS land within the Snow Talon Fire, estimates are that $80 \%$ - 95\% of the available black-backed woodpecker habitat would remain untreated, depending on which action alternative was implemented (Scott Schrenk, Helena N. F., personal communication, March 2004). Thus, under the No Action alternative there would be low risk of direct, indirect, or cumulative effects to black-backed woodpeckers.

\section{$\underline{\text { Alternative B }}$}


The proposed action would harvest approximately 170 acres due to mountain pine beetle infestation, and approximately 38 acres of overstory removal in an old shelterwood harvest. Of these acres, the 170 acres of salvage are most relevant to this species because the affected trees are of sufficient size to provide nest sites, and the level of infestation is sufficient to provide for foraging opportunities. Thus, by reducing the likelihood of the infestation spreading, the proposed action would likely reduce the availability of current and future suitable habitat for black-backed woodpeckers. At the landscape level, there currently is approximately 16,700 ac of suitable black-backed woodpecker habitat within the area burned by the Snow Talon Fire of 2003, located 3 miles north of the project area. Until 2008 or 2009, implementing the proposed harvest should have minimal effects to the black-backed woodpecker population that should inhabit the burned area, largely due to the abundance and availability of preferred habitat (Hutto 1995). However, by implementing the proposed harvest, DNRC would be reducing the amount of insectinfested forest, and likely curtailing the infestation. This would likely reduce the future availability of black-backed woodpecker habitat. Although, with the abundance of summer recreational use in the area surrounding the project area, the disturbance generated by recreationists may deter use by black-backed woodpeckers of any future insect-infested habitat. Thus, due to the localized abundance and availability of new black-backed woodpecker habitat within the burned area, and the prevalence of summer recreation on the project area, there would be low risk of cumulative effects to black-backed woodpeckers as a result of the proposed action.

\section{Big Game - Deer, Elk, and Moose}

\section{Alternative A}

Under the no action alternative, the beetle infestation would continue to spread, creating snags and simultaneously reducing canopy closure. The infestation may eventually spread to USFS lands north of the project area. As a result, snow-intercept cover would be reduced, while hiding cover would remain until the snags would eventually fall to the ground. With high levels of year round recreational use of the project and analysis areas by motorized vehicle users (e.g., snowmobiles, ATVs, pickups, etc.), and extensive open road networks in the southern portion of the analysis area (in and among winter range areas), big game would require more extensive areas of snow intercept cover near winter range to minimize energy expenditures, and hiding cover during hunting season, than may be possible under this alternative. Thus, because of the level of recreational use and potential for the infestation to spread and further reduce snow intercept and hiding cover, there would be low to moderate risk of direct, indirect, and cumulative effects to these big game species as a result the No Action alternative.

\section{Alternative B}

The proposed action would salvage harvest approximately 170 acres of lodgepole pine and other species within the project area. Such action would remove snow intercept and hiding cover on approximately $60 \%$ of the affected area due to the volume of timber that would be harvested. Although the proposed action would close the proposed new road construction and an additional 0.5 mile of existing road, further reductions in open road densities were evaluated and were deemed not to be possible at this time due to topographic or vegetative features, as well as uncontrolled access points on adjacent private lands. Coupled with extensive year round motorized vehicle use, hiding and security cover are important to big game species within this parcel.

Within the 146,851 acre cumulative effects analysis area, approximately 58,537 acres (40\%) are considered to be elk security cover. The proposed action would not change this. Additionally, of the 58,537 acres of elk security cover, 41,039 acres (70\%) are located within the Scapegoat Wilderness Area. The major reasons for the majority of elk security habitat being located within the wilderness 
boundary are largely due to the extent of open roads on private and some USFS lands, and the 2003 Snow Talon Fire, which burned much of the hiding cover within its boundaries. Because of the Snow Talon Fire, the burned area will be an area full of highly nutritious and palatable forage for several years post-fire. However, the same area will also be devoid of hiding cover until seedlings and saplings are of sufficient density and at least 4 to 6 feet in height, and will be absent snow-intercept cover for 40 to 50 years post-fire.

The analysis area is truly a gradient (NW to SE) of security cover (NW) to winter range (SE), with the fire in between. Unfortunately, the security cover occurs at the higher elevations, where most big game animals would likely only make use of them for a portion of the hunting season (depending upon winter onset), and the lower elevation security cover occurs on the fringes of the analysis area in 3 disjunct blocks, each $<4,100$ acres. Thus, big game would likely be more vulnerable to hunting pressure on their migration from summer to winter range as a result of past effects. Of the winter range within the analysis area, the proposed action would harvest timber on approximately 208 acres of winter range. Thus, the proposed action would harvest timber within winter range within the analysis area, reduce hiding cover within a project area that receives extensive recreational use, yet it would not remove any additional security cover. Additionally, the Snow Talon Fire removed mid-elevation elk security cover. Therefore, the proposed action would likely have low to moderate risk of direct, indirect, and cumulative effects for big game within the analysis area.

\section{Biological Diversity}

\section{$\underline{\text { Alternative A }}$}

Under the no action alternative, the mountain pine beetle infestation would likely grow and infest additional acres of lodgepole pine, resulting in a mosaic of lodgepole pine snags and coarse woody debris interspersed with pockets of live Douglas-fir, subalpine fir, and Engelmann spruce within the project area. While the dead wood would attract additional species of small mammals, woodpeckers, and other cavity nesting birds, the project area would see greater reductions in wildlife species richness from mature forest associated species. Additionally, the pockets of live fir and spruce that would be retained would likely not function as mature forest due to changes in microclimate from edge effects and an abundance of edge-associated species.

At the broader landscape scale, similar results to those in the project area may be seen if the mountain pine beetle infestation were to spread. However, much of the forested land in the northeast quarter of the analysis area would not likely become infested due to the young age and low stocking levels of lodgepole pine on these lands. The areas most likely to become infested would be the DNRC and USFS lands northwest of the project area because these are the lands in closest proximity to the infestation with the highest stocking levels and older forests. Should the infestation spread to these lands, there would likely be reductions in mature forest associated species and increases in early successional forest and dead wood dependent species. Thus, there would likely be moderate to high risk of direct, indirect, and cumulative effects to biodiversity as a result of the no action alternative.

\section{Alternative B}

The proposed action would salvage harvest approximately 170 acres and do an overstory removal on approximately 38 acres. As such, the proposed salvage harvest and associated removal of mature trees would reduce the amount of forest aged $\geq 100$ yrs to approximately 187 acres, and increase the amount of forest $<40$ yrs old to approximately 313 acres within the project area. Additionally, the amount of hard edge within the project area would likely increase from 36,251 ft to approximately 65,030 ft. 
Such increases in hard edge would increase the amount of edge effects on microclimate and increase the distribution of edge-related wildlife species, thereby affecting forest interior wildlife. The proposed harvest units would largely affect forest aged $\geq 100$ yrs, which would reduce overall wildlife diversity within the project area, and present future challenges for the remaining forest interior species due to resulting increases in nest parasitism and small predators. Thus, at the level of the project area (i.e., 1 square mile), there would be moderate to high risk of direct and indirect effects to biodiversity.

At the landscape level (approximately 117 square miles), low risk of cumulative effects to biological diversity would be expected as a result of the proposed action. The proposed action is designed to hopefully curtail the spread of a mountain pine beetle infestation, whose potential effects have been previously described under Alternative A, should the infestation spread. The proposed action, in conjunction with the Golden Arches and Old McDonald timber sales (see Golden Arches Environmental Analysis), would add minor increases in early successional forest to the landscape, and exist in a private lands matrix that currently favors early successional forest. The proposed action would also result in the removal of potential dead wood that would normally enter the landscape under normal conditions, thereby reducing the likelihood that there would be increases in dead wood associated wildlife species. Because of the scale involved (approximately 208 acres), there would likely be low risk of cumulative effects to biological diversity as a result of the proposed action.

\section{Connectivity and Fragmentation}

\section{Alternative A}

Under the no action alternative, as previously discussed, the mountain pine beetle infestation would likely spread, leaving disconnected and fragmented patches of mature Douglas-fir, subalpine fir, and Engelmann spruce. The resulting landscape within the project area would largely be early successional forest within 10 years. Thus, for early successional species, the project area would likely be a matrix of early successional forest with high connectivity and low fragmentation. The converse would be true for wildlife associated with older, mature forest. However, for those species susceptible to edge effects, the no action alternative would likely have high risk of edge effects due to smaller remnant mature forest patches, post-infestation. When expanded to the larger landscape (the scenario is described under Biological Diversity's Alternative A), the effects of an expanded mountain pine beetle infestation would likely result in higher connectivity among young forest landscapes on adjoining parcels, with reduced fragmentation for wildlife associated with early successional forest/open habitats. Whereas, habitat for wildlife associated with older, mature forest would likely become highly fragmented, small islands interspersed in a matrix of young forest and grassland habitat. Thus, there would likely be moderate risk of direct, indirect, and cumulative effects to habitat connectivity and fragmentation under the no action alternative.

\section{Alternative B}

Similar to the results for biological diversity at the project level, connectivity for forest aged $\geq 100$ yrs would be decreased, with increased fragmentation. However, while early forest connectivity would increase as a result of the proposed action, fragmentation of that habitat would also increase because while there would be more early forest habitat in larger patches, that habitat would be more dispersed within the project area. While fragmentation of young forest habitat would be increased, the nearest neighbor distance among these patches would be reduced, making dispersal of early forest associated species easier within the project area. 
At the landscape level (approximately 117 square miles), the proposed action would serve to begin the bottleneck of younger, more open forest's influence over the dispersal of mature forest species earlier, slightly widening the gap between mature forest patches in the northwest and southeast corners of the analysis area. Currently, between the two large patches of mature forest in opposing corners of the analysis area, there is a small linkage zone of younger, open forest at the lower elevations that also includes home sites, recreation corridors, and a state highway. The proposed action would increase this potentially less hospitable zone for mature forest wildlife. Thus, while there may still be connectivity between mature forest fragments, the connective matrix may be of low quality for some wildlife species that are influenced by home sites, recreation corridors, and highways (e.g., big game, bears, fisher, etc.). Thus, there would likely be low to moderate risk of direct, indirect, and cumulative effects to connectivity and fragmentation as a result of the proposed action alternative. 


\section{Attachment D}

Watershed, Fisheries, Soils 


\section{Watershed, Fisheries, Soils}

\section{Existing Conditions- Affected Watershed}

The Keep Cool Bug Salvage project is located on state trust land within Section 10, T14N, R8W of Lewis and Clark County. The terrain is gentle to moderately steep slopes along a broad ridge over 1 mile north of the Blackfoot River. This broad ridge forms a divide between Keep Cool Creek to the west and a small, intermittent and discontinuous tributary drainage to the Blackfoot River .The analysis area is located within the Blackfoot River watershed and considers the Keep Cool Creek watershed and the small intermittent, discontinuous tributary to the Blackfoot River within HUC 170102030301, which is 15,451 acres in area. Keep Cool Creek is a $3^{\text {rd }}$ order tributary to the Blackfoot River (HUC 17010203034) which 32,834 acres in area. Keep Cool Creek is not located within the state Section 10 or near any of the proposed road construction, existing roads proposed for access use or harvest areas. While USGS topographic maps of the area indicate that there are stream segments in the section, no streams were identified in the harvest area and draws do not have continuous or direct channel delivery to Keep Cool Creek. The proposed harvest area does contain several isolated wetlands. Elevations in the section range from 5000 to 5600 feet. Within the analysis area, average precipitation is approximately 22 inches a year, mainly as snow.

\section{Geology and Soils}

Bedrock geology is Newland limestone on the east side of Section 10 and volcanic porphyry on the northwest and west side of the section. The project area is located on gentle to moderate slopes north of the Blackfoot River. Slopes are stable and no unique geologic features occur, except for mineral potential at depth. Soils located in the project area are a combination of Worock-Mikesell soils on 8$15 \%$ slopes with steeper slopes of $20-45 \%$ in the area of the proposed overstory removal unit. Shallow rock occurs near the ridgeline, but does not limit proposed road construction. Worock soils have a gravelly loam surface over very gravelly clay loams from igneous bedrock. Worock has slight to moderate risk of erosion and moderate for windthrow, compaction and displacement. Worock soils have a slightly longer season of use. Mikesell soils have similar deep gravelly clay loams forming in glacial till and alluvium from limestone and are slightly more productive than Worock soils. Mikesell soils tend to remain wet later in the spring and have a shorter season of dry use than Worock. Both soils have similar interpretations and support Douglas-fir, lodgepole pine and ponderosa pine on welldrained sites.

Predominate slopes of 10-40\% are well suited to ground based skidding operations These soils are subject to rutting and compaction if operated on when wet. Season of use is limited to frozen ground or dry summer months because soils tend to remain wet until late in the spring (typically June).

Cumulative effects to soils can occur from repeated ground skidding entries into the harvest area and additional road construction, depending on area. Section 10 was partially harvested around 1989 and those units have principally regenerated, and revegetated with no erosion problems or major impacts. No cumulative effects to soils in the area were noted based on skid trail spacing and re-entry would be limited to the overstory unit of 37 acres. No previous entries have occurred on the proposed bug salvage sites.

\section{Fisheries}


There are no streams located within the immediate project area including the proposed harvest units and along or crossing the proposed access roads. The project area also does not contain any drainage features with direct connectivity to streams or downstream fisheries habitat. Therefore there are no existing direct, indirect or cumulative impacts to fisheries occurring with the proposed project area and no road crossings of streams associated with this project.

\section{Regulatory}

The Clark Fork River drainage, including tributaries to the Blackfoot River, is classified as B-1 in the Montana Surface Water Quality Standards. The B-1 classification is for multiple use waters suitable for domestic use after conventional treatment, growth and propagation of cold-water fisheries, associated aquatic life and wildlife, agricultural, and industrial uses. Among other criteria for B-1 waters, no increases are allowed above naturally occurring concentrations of sediment, which will prove detrimental to fish or wildlife. Naturally occurring includes conditions or materials present from runoff on developed land where all reasonable land, soil, and water conservation practices have been applied. Reasonable practices include methods, measures, or practices that protect present and reasonably anticipated beneficial uses. The State has adopted Forestry Best Management Practices through its Non-point Source Management Plan as the principle means of controlling non-point source pollution from silvicultural activities.

No water rights or developments are listed within the state section or along the access route. Downslope beneficial uses in the Blackfoot River area include: domestic water sources, irrigation, livestock watering, wildlife, and cold-water fisheries

\section{Water Quality}

The proposed haul route begins at a gravel pit 3 miles east of Lincoln and climbs across gravelly soils on private lands to the SE corner of Section 10. The existing access roads or planned roads do not cross any streams and are not located in areas adjacent to streams or wetlands where sediment delivery to surface waters could occur. Existing access roads across private land and state include short steep grades that do not currently have adequate surface drainage to meet BMP's. These road segments have surface erosion, and require additional drainage and maintenance, but no sedimentation or water quality effects occur on the state or private access roads.

Within the Blackfoot watershed area, a segment of the Blackfoot River west of Landers Fork has been identified as an impaired water body in the 303(d) list that appears in the 2004 Montana 305(b) Report. Portions of the Blackfoot River are naturally dewatered in this segment . The 303(d) list was compiled by the Montana Department of Environmental Quality as required by Section 303(d) of the Federal Clean Water Act and the EPA Water Quality Planning and Management Regulations (40 CFR, Part 130). Under these laws, the State was required to identify water bodies that do not fully meet water quality standards or beneficial uses are threatened. There is no stream connectivity between the proposed sale area and Keep Cool Creek or the Blackfoot River and no non-point sources of sediment in Section 10, T14N, R8W or along the existing access road.

\section{Cumulative Watershed Effects}

DNRC completed a coarse filter evaluation of watershed conditions and cumulative effects as outlined in the Forest Management Rules (ARM 36.11.423) concerning watershed management. The 
cumulative watershed effects analysis area considered Section 10, T14N, R18W, where the proposed harvest is planned, the adjacent ephemeral drainages and along the access route. Approximately 35 acres of salvage harvest (1\% of basin) is planned within the Keep Cool Creek watershed on moderate slopes with no stream connectivity and thus was dismissed from further analysis due to low risk of watershed effects. The coarse filter approach consisted of on-site evaluation, of harvest areas and roads, and assessing the extent of past harvest activities, through the use of maps and aerial photographs. .

Mountain pine beetle infestations have caused patches of tree mortality and associated loss of tree canopy, evapo-transpiration potential and snow interception. The small patchy nature of the current tree mortality is unlikely to cause measurable changes in water yield or cumulative effects. A trend towards more extensive infestations or possibly wildfire could considerably reduce tree canopy and may increase water yield in the future, but is unlikely to result in overland flow due to the discontinuous and ephemeral drainages and isolated wetlands that provide water storage. No cumulative watershed effects from off-site sedimentation from roads or previous harvest units were identified in the project area.

\section{Potential Effects of the Proposed Actions}

\section{Alternative A}

The effects of the no action alternative would be the same as previously described under existing conditions for soils, water quality and fisheries.

\section{Alternative B}

The proposed prescription is to salvage harvest dead, dying and high-risk trees on up to 170 acres with group selection and singletree selection on moderate slopes of 5-45\%. The salvage harvest would be patchy in distribution reflective of the insect caused tree mortality with individual tree selection and small clear-cuts up to approximately 5 acres in size. Overstory seed trees would be harvested from a regenerated cutting unit on 38 acres.

Approximately 1/2 mile of new low standard road would be constructed on moderate sideslopes of primarily less than $20 \%$ with minimal grade and excavation. The new road would be grass seeded and closed to traffic after use. Adequate drainage would be installed in all existing and new roads to meet BMP's. About 1 mile of existing road would be effectively closed, and thus reduce total open road miles by 0.5 miles. No streams occur along the access road or proposed road and no stream crossings are proposed.

\section{Soil Resources}

Primary soil concern is minimizing detrimental soil impacts of displacement, compaction and rutting of shallow surface soils to retain soil properties important to growth and reduce overstocking. The overstory harvest involves few trails with low volumes and operations are low risk of direct, indirect and cumulative impacts to soils. For the proposed harvest, BMP's and mitigations would be implemented to minimize the area and degree of detrimental soil impacts (displacement, erosion, compaction). Mitigations include general skid trail planning, limit tractors to moderate slopes, avoiding wetlands and controlling soil disturbance to meet silvicultural goals to promote conifer regeneration. Large woody debris would be maintained on the site at approximately 5-15 tons/acre, 
(Graham 1994) well distributed and trampled to help maintain nutrient cycling for long term soil productivity, and to encourage reforestation.

With the implementation of BMP's and the recommended mitigation measures soil impacts are expected to be less than $20 \%$ of the area. It is expected that by protecting 80 to $85 \%$ of harvest area in non-detrimental soil impacts, soil productivity would be maintained (DNRC 1998, 2004). Sale administrators would monitor on-going harvest activities to meet; contract requirements, BMP'S for soil and water protection and silvicultural objectives. The proposed harvest operations are expected to maintain soil properties important to, plant growth and hydrologic function and present low risk of direct, indirect and cumulative impacts to soils. Portions of existing roads that have inadequate drainage and do not comply with BMP's would be repaired to improve drainage and control erosion.

\section{Water Quality}

The proposed ground based timber harvest and road construction is expected to result in low risk of water quality impacts due to erosion and sediment delivery. All wetlands, seeps and discontinuous stream segments would be avoided or protected with equipment restriction where needed to prevent excessive levels of soil disturbance and erosion. There are no streams with continuous surface delivery to Keep Cool Creek or other downstream water resources located within or adjacent to the proposed harvest units. No stream crossings occur on the existing access roads or on proposed roads. Therefore, there would be no risk of sediment delivery to surface waters. The installation of additional drain-dips in the existing road system would be expected to improve surface drainage and reduce current erosion along existing roads. Road closures would result in a 1/2 mile reduction in total open roads and reduce long term maintenance needs.

DNRC would implement all applicable BMPs, and reasonable mitigation and erosion control practices during timber harvest, road maintenance, road construction and road use activities to control erosion and potential for sediment delivery. The potential for increase in water yield resulting from the proposed harvest is expected to be negligible compared to no-action, considering this is mainly a salvage harvest of dead and dying trees.

Therefore, no direct or indirect impacts to water quality or downstream beneficial uses are expected.

\section{Cumulative Watershed Effects}

There is low risk of cumulative watershed impacts due to water and sediment yield increases occurring from this proposal due to the following reasons. The moderate precipitation zone (22”/yr), low level of additional canopy removal and patchy nature of harvest would not noticeably increase water yield compared to the no-action of leaving dead trees with lost canopy interception and evapotranspiration. Previous harvesting within the section is over $60 \%$ recovered. The existing and proposed levels of harvest are below the levels normally associated with detrimental increases in water yield, peak flow, or duration of peak flows. The proposed ground based timber harvest and road construction is expected to result in low risk of erosion or sediment and existing road drainage would be improved to reduce erosion and maintenance. For these reasons, no direct, indirect, or cumulative impacts to water quality or beneficial uses are anticipated to result from the proposed actions

\section{Fisheries}


There are no fish bearing streams within the timber sale project area. No direct, indirect or cumulative impacts to downstream fisheries are expected under the proposed action alternative due to the following reasons: 1) There are no streams or SMZ's within the proposed harvest areas; 2) draws are ephemeral and lack downstream delivery potential within the immediate vicinity of the proposed harvest areas; 3) the proposed road construction and existing access road does not include any steam crossings or road construction in SMZ's. For these reasons; no increase in the sediment delivery, no increase in stream temperatures, or loss of potential large woody debris recruitment is expected to occur as a result of the proposed action alternative.

\section{General Design and Mitigations for Harvest Units}

* The logger and sale administrator should agree to a general skidding plan prior to equipment operations on complex terrain or draw crossings.

* Limit equipment operations to periods when soils are relatively dry, frozen or snow covered to minimize soil rutting, compaction and maintain drainage features.

* On moderate to densely stocked stands, whole tree skidding can reduce slash hazard, but also remove a portion of nutrients from growing sites. Harvest operations should retain a portion of available green slash to provide for erosion control on trails where needed and nutrient cycling to maintain soil productivity. Target woody debris levels are to retain 5-15 tons/acre well distributed on site while meeting the requirements for fire protection. The amounts would vary based on the extent of harvest from single tree selection to small clearcuts. 


\section{Attachment E Economics}




\section{Economics}

\section{Project Costs and Revenues}

The following assumptions were used to estimate the revenue and site treatment costs for each alternative:

1. The harvested volumes for the alternatives were estimated by Clearwater Unit personnel.

2. The stumpage value was estimated using a residual value approach. The estimated stumpage value equals the delivered log prices subtracted from logging cost, haul cost, Forest Improvement (FI) fee, development cost and an amount for profit and risk. The amount for profit and risk was based on $15 \%$ of the logging and hauling costs.

3. The estimated delivered log price is based on a telephone quote to the closest mill, which is the Pyramid Mountain Lumber mill in Seeley Lake.

TABLE E-1

Residual Value Appraisal (per MBF)

\begin{tabular}{|l|l|}
\hline & Alternative B \\
\hline \hline Delivered Log Prices & $\$ 450$ \\
\hline Logging Cost & $\$ 115$ \\
\hline Haul Cost & $\$ 39$ \\
\hline Development Costs & $\$ 10$ \\
\hline Forest Improvement Fee & $\$ 17$ \\
\hline Profit and Risk & $\$ 23$ \\
\hline Estimated Stumpage Value & $\$ 246$ \\
\hline
\end{tabular}

4. Development costs were estimated for each alternative by Clearwater Unit personnel. Development costs on this proposal are the estimated costs of roads, easement acquisition and watershed improvement items that would be paid for by the purchaser. These improvements provide access to the State Trust Lands involved and improve water quality on state land and downstream.

5. Forest Improvement (FI) cost is based on the cost to maintain the ongoing staffing, stand and road maintenance treatment needs for the current year, right-of-way acquisition and program wide costs. Funds collected under FI from a purchaser provide the State with funding to accomplish projects such as tree planting, site preparation, slash treatment, thinning, road maintenance, right-of-way acquisition, and for some timber sale related activities. Thus, the State is able to improve the long-term productivity of timber stands on state land and maintain or acquire access for future revenue producing projects. 
6. Sale specific FI costs are the current cost estimates for the amount and types of treatments (site preparation, hazard reduction, planting, etc.) that would be done related to each of the alternatives being considered. Funding to complete these projects will be collected from current or future timber sales depending on the timing of the treatments.

7. Limitations of the economic analysis: (a) Only known costs and benefits that are related to timber harvesting activities are considered; (b) None of the potential nonmarket benefits associated with leaving trees (i.e., snag recruitment, structural diversity, aesthetics, wildlife habitat, nutrient recycling, etc.) are considered.

8. The costs related to the administration of the timber sale program are only tracked at the Land Office and state wide level. DNRC does not keep track of these costs for individual timber sales.

9. Costs, revenues, and estimates of return are estimates intended for relative comparison of alternatives. They are not intended to be used as absolute estimates of return.

10. The school trust currently receives income from grazing activities on the parcel. This activity is independent from the proposed project, although the action alternatives would create a temporary increase in forage for livestock. The proposed activities are not expected to decrease the revenue from or value of the lease lots in and around the proposed activities.

TABLE E-2

Costs and Revenues Associated With This Project by Alternative

\begin{tabular}{|l|l|l|}
\hline & Alternative A & Alternative B \\
\hline 1. Harvest Volume (MBF) & 0 & 1300 \\
\hline 2. Development Cost (\$/MBF) & 0 & $\$ 10$ \\
\hline 3. Stumpage Value (\$/MBF) & 0 & $\$ 246$ \\
\hline $\begin{array}{l}\text { 4. Forest Improvement Cost (FI) } \\
\text { (\$/MBF) }\end{array}$ & 0 & $\$ 17$ \\
\hline $\begin{array}{l}\text { 5. Stumpage Value, FI Cost, and } \\
\text { Development Cost (\$/MBF) } \\
\text { (line 2 + line 3 + line 4) }\end{array}$ & 0 & $\$ 273$ \\
\hline $\begin{array}{l}\text { 6. Total \$ Value based on Stumpage } \\
\text { Value, FI Cost, and Development } \\
\text { Cost times Harvest Volume } \\
\text { (line 5 x line 1) }\end{array}$ & 0 & $\$ 354,900$ \\
\hline $\begin{array}{l}\text { 7. Stumpage Value and FI Cost } \\
\text { (\$/MBF) (line 3 + line 4) }\end{array}$ & 0 & $\$ 263$ \\
\hline $\begin{array}{l}\text { 8. Total \$ Revenue to the State } \\
\text { (line 7 x line 1) }\end{array}$ & 0 & $\$ 341,900$ \\
\hline \hline
\end{tabular}




\begin{tabular}{|l|l|l|}
\hline & Alternative A & Alternative B \\
\hline $\begin{array}{l}\text { 9. Total \$ Revenue to the Trust } \\
\text { (line 1 x line 3) }\end{array}$ & 0 & $\$ 319,800$ \\
\hline $\begin{array}{c}\text { 10. Current Lease Revenue to the Trust } \\
\text { From the Project Area (\$/year) }\end{array}$ & $\$ 498$ & $\$ 498$ \\
\hline 11. Sale Specific FI Cost (\$/MBF) & 0 & $\$ 8$ \\
\hline $\begin{array}{l}\text { 12. Total \$ Sale Specific FI Cost } \\
\text { (line 11 x line 1) }\end{array}$ & 0 & $\$ 10,400$ \\
\hline
\end{tabular}

\section{Costs and Revenues from the DNRC Forest Management Program}

The DNRC does not have an accounting system to track costs for individual projects from start to finish. An annual cash flow analysis is conducted of the DNRC's forest product sales program. Revenue and costs are calculated by land office and state-wide. The revenue-to-cost ratio for the Southwestern Land Office for fiscal year 2004 was 2.74 which was up from 2003 at 1.61 and 2002 at 2.57, and averages above the statewide ratio of just under 2 to 1 . Roughly, for every $\$ 1$ spent by the agency on managing its lands, it brings in approximately $\$ 2$ in revenue.

Total revenue is revenue from the forest management program including timber sales, permits, FI and road maintenance. Total cost is the sum of timber operating and general administration costs. Net return is total revenue less total cost.

\section{Alternative A}

As the preceding table shows, only grazing would be generating income for the associated school trust (public buildings) from this parcel of state land. No additional income would be generated as a result of this project. The timber stands would continue to grow at poor rates.

\section{Alternative B}

Approximately $\$ 341,900$ would be generated to the state of Montana as a result of the proposed action. Approximately $\$ 319,800$ of that would go to the public buildings trust. The timber harvesting in the proposed project is designed to maximize revenue to the trust accounts by capturing value in the presentterm and by improving growth rates on the harvested acres. Harvesting would create growing space for residual trees and initiate young vigorously growing regeneration. This would greatly increase the annual growth of wood fiber produced on the site, which would help to maximize revenue from these lands in the long-term. None of the proposed management activities would preclude this tract of land from other future income generating uses and no cumulative impacts are expected to occur as a result of the proposed project. 


\section{Attachment F Literature Cited}




\section{Literature Cited}

Buehler, D. A. 2000. Bald eagle (Haliaeetus leucocephalus). Pages 1-40 in The Academy of Natural Sciences; The American Ornithologists' Union, Philadelphia, Pennsylvania.

Bull, E. L., S. R. Peterson, and J. W. Thomas. 1986. Resource partitioning among woodpeckers in northeastern Oregon. E. L. Bull, S. R. Peterson, and J. W. Thomas (Resource partitioning among woodpeckers in northeastern Oregon. U. S. Department of Agriculture, Forest Service, Pacific Northwest Research Station, Portland, Oregon. Research Note PNW-444.

Clem, M. K. 1977. Food habits, weight changes and habitat use of fisher Martes pennanti during winter. M. S. Thesis, University of Guelph, Guelph, Ontario.

Coulter, M. W. 1966. Ecology and management of fishers in Maine. Dissertation, Syracuse University, Syracuse, New York.

Fischer, W.C. and A.F. Bradley. 1987. Fire ecology of western Montana forest habitat types. USDA Forest Service, Intermountain Research Station. GTR INT-223.

Hewitt, D. G. and C. T. Robbins. 1996. Estimating grizzly bear food habits from fecal analysis. Wildlife Society Bulletin 24:547-550.

Graham, Russell T.; Harvey, Alan;, Jurgensen, Martin; Jain,T.; 1994. Managing Coarse Woody Debris in Forests of the Rocky Mountains. Res. Paper INT-RP-477. Ogden, Utah: U.S.D.A., F.S., Intermountain Research Station, 12p.

Hutto, R. L. 1995. Composition of bird communities following stand-replacement fires in northern Rocky Mountain (U.S.A.) conifer forests. Conservation Biology 9:1041-1058.

Kasworm, W. F. and T. L. Manley. 1990. Road and trail influences on grizzly bears and black bears in northwest Montana. International Conference on Bear Research and Management 8:79-84.

Kelly, G. M. 1977. Fisher (Martes pennanti) biology in the White Mountain National Forest and adjacent areas. Dissertation, University of Massachusetts, Amherst, Massachusetts.

Koehler, G. M. 1990. Population and habitat characteristics of lynx and snowshoe hares in north central Washington. Canadian Journal of Zoology 68:845-851.

McClelland, B. R., S. S. Frissell, W. C. Fischer, and C. H. Halvorson. 1979. Habitat management for hole-nesting birds in forests of western larch and Douglas-fir. Journal of Forestry 77:480-483.

MTDEQ (Montana Department of Environmental Quality). 2004. Montana 2004 305(b) Report. Helena, MT.

MFISH (Montana Fisheries Information System). 2005. Montana Fish, Wildlife and Parks and Natural Resource Information System. Helena, MT.

Montana Bald Eagle Working Group. 1994. Montana bald eagle management plan. Montana Bald 
Eagle Working Group (Montana bald eagle management plan. U. S. Department of Interior, Bureau of Land Management, Billings, Montana.

Montana Department of Natural Resources and Conservation, 2004. DNRC Compiled Soil Monitoring Report on Timber Harvest Projects 1988-2004., Trust Land Management Division, Forest Management Bureau, Missoula, MT.

Montana DNRC. 2003. Montana Administrative Rules for Forest Management on DNRC Forested Lands. Montana DNRC. Trust Lands Management Division. Helena, MT.

Montana Natural Heritage Program. 2003. Data on sensitive species in Montana. Helena, MT.

Mowat, G., G. Poole, and M. O'Donoghue. 2000. Ecology of lynx in northern Canada and Alaska. Pages 265-306 in L. F. Ruggiero, K. B. Aubry, S. W. Buskirk, G. M. Koehler, C. J. Krebs, K. McKelvey, and J. R. Squires (eds.). Ecology and conservation of lynx in the United States. U. S. Department of Agriculture, Forest Service, Rocky Mountain Research Station, Ft. Collins, Colorado. General Technical Report RMRS-GTR-30WWW.

Niccolucci, M. 1996. Personnal communication. USFS Rocky Mountain Research Station. Missoula, MT.

Pfister, R.D. and B.L. Kovalchik, S.F. Arno, R.C. Presby. 1977. Forest habitat types of Montana. USDA Forest Service, Intermountain Station, GTR INT-34.

Pierson, E. D., M. C. Wackenhut, J. S. Altenbach, P. Bradley, P. Call, D. L. Genter, C. E. Harris, B. L. Keller, B. Lengus, L. Lewis, B. Luce, K. W. Navo, J. M. Perkins, S. Smith, and L. Welch. 1999. Species conservation assessment and strategy for Townsend's big-eared bat (Corynorhinus townsendii and Corynorhinus townsendii pallescens). Idaho Department of Fish and Game, Boise, Idaho.

Powell, R. A. 1977. Hunting behavior, ecological energetics and predator-prey community stability of the fisher (Martes pennanti). Dissertation, University of Chicago, Chicago, Illinois. 1978. A comparison of fisher and weasel hunting behavior. Carnivore 1:28-34.

Ruediger, B., J. Claar, S. Gniadek, B. Holt, L. Lewis, S. Mighton, B. Naney, G. Patton , T. Rinaldi, J. Trick, A. Vandehey, F. Wahl, N. Warren, D. Wenger, and A. Williamson. 2000. Canada lynx conservation assessment and strategy. U. S. Department of Agriculture, Forest Service, Missoula, Montana. R1-00-53.

Squires, J. R. and T. Laurion. 2000. Lynx home range and movements in Montana and Wyoming: preliminary results. Pages 337-349 in L. F. Ruggiero, K. B. Aubry, S. W. Buskirk, G. M. Koehler, C. J. Krebs, K. McKelvey, and J. R. Squires (eds.). Ecology and conservation of lynx in the United States. U. S. Department of Agriculture, Forest Service, Rocky Mountain Research Station, Ft. Collins, Colorado. General Technical Report RMRS-GTR-30WWW.

USDA Forest Service R-1, and Montana Department of State Lands, Idaho Department of State Lands. 1991. Forest insect and disease identification and management. Missoula, MT. 
U.S. Forest Service. Interior Columbia River Basin (ICRB) Draft EIS, Vol.1, 1997.

Waller, J. S. and R. D. Mace. 1997. Grizzly bear habitat selection in the Swan Mountains, Montana. Journal of Wildlife Management 61:1032-1039. 


\section{Attachment G \\ List of Preparers and Contributors}




\section{List of Preparers and Contributors}

Kamps, Steven

Collins, Jeff

McGrath, Mike

Nelson, Craig

Rennie, Patrick
Forest Management Specialist, Clearwater Unit

Department of Natural Resources and Conservation Lincoln, MT

Hydrologist/Soils Scientist, Southwestern Land Office Department of Natural Resources and Conservation Missoula, MT

Wildlife Biologist, Southwestern Land Office

Department of Natural Resources and Conservation

Missoula, MT

Supervisory Forester, Clearwater Unit Department of Natural Resources and Conservation Greenough, MT

Archaeologist, Agriculture and Grazing Management Bureau Department of Natural Resources and Conservation Helena, MT 


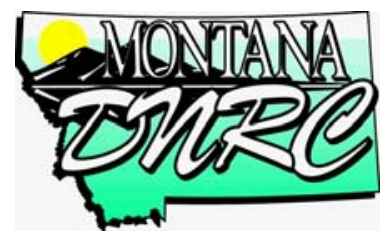

MONTANA DEPARTMENT OF NATURAL RESOURCES AND CONSERVATION

\section{LINCOLN FILED OFFICE OF THE CLEARWATER UNIT \\ PO BOX 127 \\ LINCOLN, MT 59639}

(406) $362-4999$

Persons with disabilities who need an alternative, accessible format of this document should contact the DNRC at the above address or phone number.

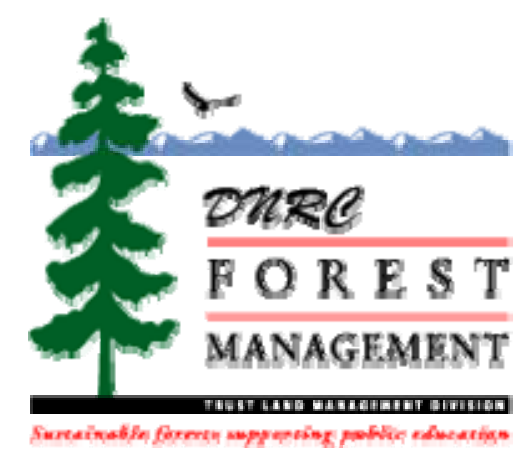

12 copies of this document were published at an estimated cost of \$10.83 per copy. The total cost includes $\$ 129.96$ for printing/binding and $\$ 0$ for distribution. 